OPEN ACCESS

Edited by:

Lechun Xie,

Wuhan University of Technology,

China

Reviewed by:

Jian Wang,

Xihua University, China

Ke Zhan,

University of Shanghai for Science

and Technology, China

*Correspondence:

Yujin Tang

tangyujin196709@163.com

Junlin Yang

yjunlin@126.com

${ }^{\dagger}$ These authors have contributed equally to this work

Specialty section: This article was submitted to Biomaterials,

a section of the journal Frontiers in Bioengineering and

Biotechnology

Received: 25 May 2020 Accepted: 26 June 2020 Published: 17 July 2020

Citation:

Attarilar S, Yang J, Ebrahimi M, Wang $Q$, Liu J, Tang Y and Yang J (2020) The Toxicity Phenomenon and the Related Occurrence in Metal and Metal Oxide Nanoparticles: A Brief Review From the Biomedical

Perspective.

Front. Bioeng. Biotechnol. 8:822. doi: 10.3389/fbioe.2020.00822

\section{The Toxicity Phenomenon and the Related Occurrence in Metal and Metal Oxide Nanoparticles: A Brief Review From the Biomedical Perspective}

\author{
Shokouh Attarilar ${ }^{1 \dagger}$, Jinfan Yang ${ }^{2 t}$, Mahmoud Ebrahimi ${ }^{3}$, Qingge Wang ${ }^{4}$, Jia Liu ${ }^{5}$, \\ Yujin Tang ${ }^{5 *}$ and Junlin Yang ${ }^{1 *}$
}

' Department of Pediatric Orthopaedics, Xin Hua Hospital Affiliated to Shanghai Jiao Tong University School of Medicine, Shanghai, China, ${ }^{2}$ Department of Spine Surgery, Xin Hua Hospital Affiliated to Shanghai Jiao Tong University School of Medicine, Shanghai, China, ${ }^{3}$ National Engineering Research Center of Light Alloy Net Forming, School of Materials Science and Engineering, Shanghai Jiao Tong University, Shanghai, China, ${ }^{4}$ School of Metallurgical Engineering, Xi'an University of Architecture and Technology, Xi'an, China, ${ }^{5}$ Affiliated Hospital of Youjiang Medical University for Nationalities, Baise, China

Thousands of different nanoparticles (NPS) involve in our daily life with various origins from food, cosmetics, drugs, etc. It is believed that decreasing the size of materials up to nanometer levels can facilitate their unfavorable absorption since they can pass the natural barriers of live tissues and organs even, they can go across the relatively impermeable membranes. The interaction of these NPs with the biological environment disturbs the natural functions of cells and its components and cause health issues. In the lack of the detailed and comprehensive standard protocols about the toxicity of NPs materials, their control, and effects, this review study focuses on the current research literature about the related factors in toxicity of NPs such as size, concentration, etc. with an emphasis on metal and metal oxide nanoparticles. The goal of the study is to highlight their potential hazard and the advancement of green non-cytotoxic nanomaterials with safe threshold dose levels to resolve the toxicity issues. This study supports the NPs design along with minimizing the adverse effects of nanoparticles especially those used in biological treatments.

Keywords: non-cytotoxic materials, nanomaterials, cytotoxicity, nanomedicine, metal oxide nanoparticles, nanotoxicology

\section{INTRODUCTION}

Nanoparticles (NPs) are defined as materials with two dimensions in the range of $1-100 \mathrm{~nm}\left(10^{-9}\right.$ $\mathrm{m}$ ), while nanomaterials are determined as materials possessing just one dimension in that range according to ASTM E2456 standard (ASTM, 2012). These NPs can have a variety of shapes with different aspect ratios including nanorods with $<10$ aspect ratio, spherical, cubical, and other possible shapes. Owing to this nanometric size level, NPs can have versatile size-dependent and special properties such as catalytic, electrochemical, optical, magnetic features as well as increased surface to volume ratios which in turn make them the unique materials for modern applications. 
Metal oxide nanoparticles are amidst the most widely used NPs in a variety of applications including cosmetics (Waghmode et al., 2019), drug and medicine industry (Klębowski et al., 2018), detergents, agricultural systems (Chen, 2018), environment (Kanchi and Ahmed, 2018), antibacterial agents (Mordorski and Friedman, 2017), paints and textiles (Vigneshwaran et al., 2010). Nowadays, some metallic NPs including gold NPs (Au NPs), silver NPs (Ag NPs), and metallic magnetic NPs such as ironoxide NPs (IONPs) are frequently utilized and improved in order to intensify their functions as diagnostic and remedial agents. Table 1 lists some applications of the common metallic NPs.

Metallic NPs' design and their modification can be done through versatile surface functionalities so they can be conjoined with antibodies, ligands, and drugs, consequently raise their potential applications in biotechnology, drug and gene delivery, magnetic separation and imaging, besides the favorable characteristics they have a potential to cause harmful effects if they enter to live biological systems and tissues (Yang et al., 2018; Gu et al., 2019; Liu et al., 2019; Wang L. et al., 2019). Unfortunately, there are many ways for unwanted and spontaneous entry of NPs to the body system, whether through the air we breathe or the water we drink, also foods, medicines, clothes, and cosmetics are no exception. The main entry routes can be considered as inhalation through the respiratory tract, by transudation through the skin and by ingestion through the digestive tract (Zoroddu et al., 2014). Therefore, nanomaterials released into the body environment seem to be inevitable and may have some unforeseen harmful effects hence it is of crucial importance to study their toxicity-related issues. This subject becomes of more paramount importance if we know that their nanoscale size facilitates their penetration to different live tissues and enables possible interaction with the same sized organs like cells, proteins, and antibodies also they can accumulate in organs and tissues as a foreign body (Nemmar et al., 2002; Nel et al., 2006). This arises from the high surface area for example in the case of two NPs with the same mass, smaller NPs have a larger specific surface area and thus provide a more available area to cellular interactions with nucleic acids, proteins, fatty acids, and carbohydrates (Huang et al., 2017). Considering the so-called issues, a new branch of research was introduced and entitled "Nanotoxicology" which deals with the nanomaterials toxicity (Pacheco et al., 2007). Unfortunately, there have not been yet any comprehensive and precise standard protocols for cytotoxicity of various materials, however, about the NPs, the concentration, composition, size, charge, and other physicochemical factors are considered for material selection and their possible utilization. Various methods are used in order to estimate the cytotoxicity levels of NPs which is categorized into two main groups of in vitro and in vivo methods. In this regard, the in vitro group includes dye exclusion assays (trypan blue exclusion and erythrosin B dye exclusion assays), colorimetric assays (MTT, WST-1, neutral red uptake and lactate dehydrogenase assays), fluorescencebased assays (Alamar blue and protease-based viability assays), luminometric methods (Adenosine triphosphate based method), cell viability test in real-time (estimation of oxidative stress, ROS level measurement, lipid peroxidation, glutathione estimation), apoptosis based assays (Annexin-V FITC/propidium Iodide and TUNEL assays. For determining the level of genotoxicity of nanoparticles in vitro, micronucleus formation, cytokinesis block micronucleus, flow micronucleus, and comet assays can be utilized. In vivo characterization of toxicity can be done through quantitation and bio-distribution of NPs from tissues, electron microscopy and detection of NPs accumulation, liquid scintillation counting, and NPs' quantification by drug loading and release. Also, the whole body imaging-based methods are utilized for estimation of NPs' toxicity and bio-distribution such as in vivo optical imaging, computed tomography, magnetic resonance, and nuclear medicine imaging, for more information about cytotoxicity assessment, the readers can refer to (Shah et al., 2020). The main objective of these nanotoxicology experiments and studies is the comprehensive understanding in relation to the toxicity of quantum size effects, shape, and high surface area to volume ratio of nanomaterials in biological environments. In this regard and considering the generally used metal and metal oxide NPs, this review paper focuses on the nanotoxicology of these materials with special attention to the physical properties of NPs and their effects on toxicity. Also, the involved mechanisms in relation to nanotoxicology will be addressed.

\section{MECHANISMS OF NANOTOXICOLOGY}

A lot of toxicity mechanism is involved with NPs and the most common types can be listed as below and are shown in Figure 1. As shown in Figure 1, NPs have the ability to interact with most of the cell components from DNA and various proteins to mitochondria, they can lead to reactive oxide species (ROS) formation and affect the different functions of cell. In this regard, DNA damage, lysosomal hydrolases, ROS generation, mitochondrial dysfunction, apoptosis, cell membrane damage, cytoplasm impairment, alterations in ATP, and permeability of cell membrane, accumulation of NPs in Golgi and variations in proteins all can be attributed to NPs interaction.

\section{Reactive Oxygen Species Formation}

The imbalance between production and accumulation of oxygen reactive species (ROS) leads to the occurrence of oxidative stress in cells and live tissues. ROS generates by mitochondria during both physiological and pathological conditions and they are considered as the metabolic by-products of biological systems (Pizzino et al., 2017). They can also be referred to as free radicals and have favorable functions at low or moderate concentrations, they fight with pathogens and are necessary to cell signaling and synthesize various cellular structures and proteins (Dröge, 2002). However, in high concentrations, oxidative stress (OS) condition takes place in which ROS suppress the live cells and organs' ability to detoxify and unfortunately, it can damage proteins, lipids, and nucleic acids, and severely leads to cell death and disease development including cancer (Katerji et al., 2019).

Oxidative stress biomarkers can be categorized in two groups of (a) ROS modified molecules generation and (b) deterioration or derivation of enzymes or antioxidants, the trace of these biomarkers can be detected in body fluids (Tsukahara, 2007). Although due to its unstable condition it 
TABLE 1 | Application of some metallic and metal oxide nanoparticles.

\begin{tabular}{|c|c|}
\hline Metals & Application of metallic and metal oxide nanoparticles \\
\hline Titanium dioxide (Ti) & $\begin{array}{l}\text { Solar cells, food wraps, medicines, pharmaceuticals, lacquers, construction, medical devices, gas sensing, } \\
\text { photocatalyst, agriculture, paint, food, cosmetic, sterilization, antibacterial coatings (Waghmode et al., 2019). }\end{array}$ \\
\hline Zinc and Zinc oxide (Zn) & Medical and healthcare goods, sunscreens, packaging, UV-protective materials such as textiles. \\
\hline Aluminum (Al) & Automobile industry, aircraft, heat shielding coatings, military application, corrosion, fuel additive/propellant. \\
\hline Gold (Au) & $\begin{array}{l}\text { Sensory probes, cellular imaging, electronic conductors, drug delivery, therapeutic agents, organic photovoltaics, } \\
\text { catalysis, nanofibers, textiles. }\end{array}$ \\
\hline Iron (Fe) & $\begin{array}{l}\text { Magnetic imaging, environmental remediation, glass and ceramic industry, memory tape, resonance imaging, plastics, } \\
\text { nanowires, coatings, textiles, alloy and catalyst applications. }\end{array}$ \\
\hline Silica (Si) & $\begin{array}{l}\text { Drug and gene delivery, adsorbents, electronic, sensor, catalysis, remediation of the environment pollutants, additive in } \\
\text { rubber and plastic industry, filler, electric and thermal insulators. }\end{array}$ \\
\hline Silver (Ag) & $\begin{array}{l}\text { Antimicrobial coatings, textiles, batteries, surgery, wound dressings, biomedical devices, photography, electrical } \\
\text { devices, dental work, burns treatment. }\end{array}$ \\
\hline Copper (Cu) & $\begin{array}{l}\text { Biosensors and electrochemical sensors, plastic additives like anti-biotic, anti-microbial, and anti-fungal agent, coatings, } \\
\text { textiles, nanocomposite coating, catalyst, lubricants, inks, filler. }\end{array}$ \\
\hline Cerium $(\mathrm{Ce})$ & $\begin{array}{l}\text { Chemical mechanical polishing/planarization, computer chip, corrosion, solar cells, fuel oxidation catalysis, automotive } \\
\text { exhaust treatment (Dhall and Self, 2018). }\end{array}$ \\
\hline Manganese and its oxides (Mn) & $\begin{array}{l}\text { Molecular meshing, solar cells, batteries, catalysts, optoelectronics, drug delivery ion-sieves, imaging agents, magnetic } \\
\text { storage devices, water treatment and purification (Hoseinpour and Ghaemi, 2018; Wang W. et al., 2019). }\end{array}$ \\
\hline Nickel (Ni) & $\begin{array}{l}\text { Fuel cells, membrane fuel cells, automotive catalytic converters, plastics, nanowires, nanofibers, textiles, coatings, } \\
\text { conduction, magnetic properties, catalyst, batteries, printing inks. }\end{array}$ \\
\hline
\end{tabular}

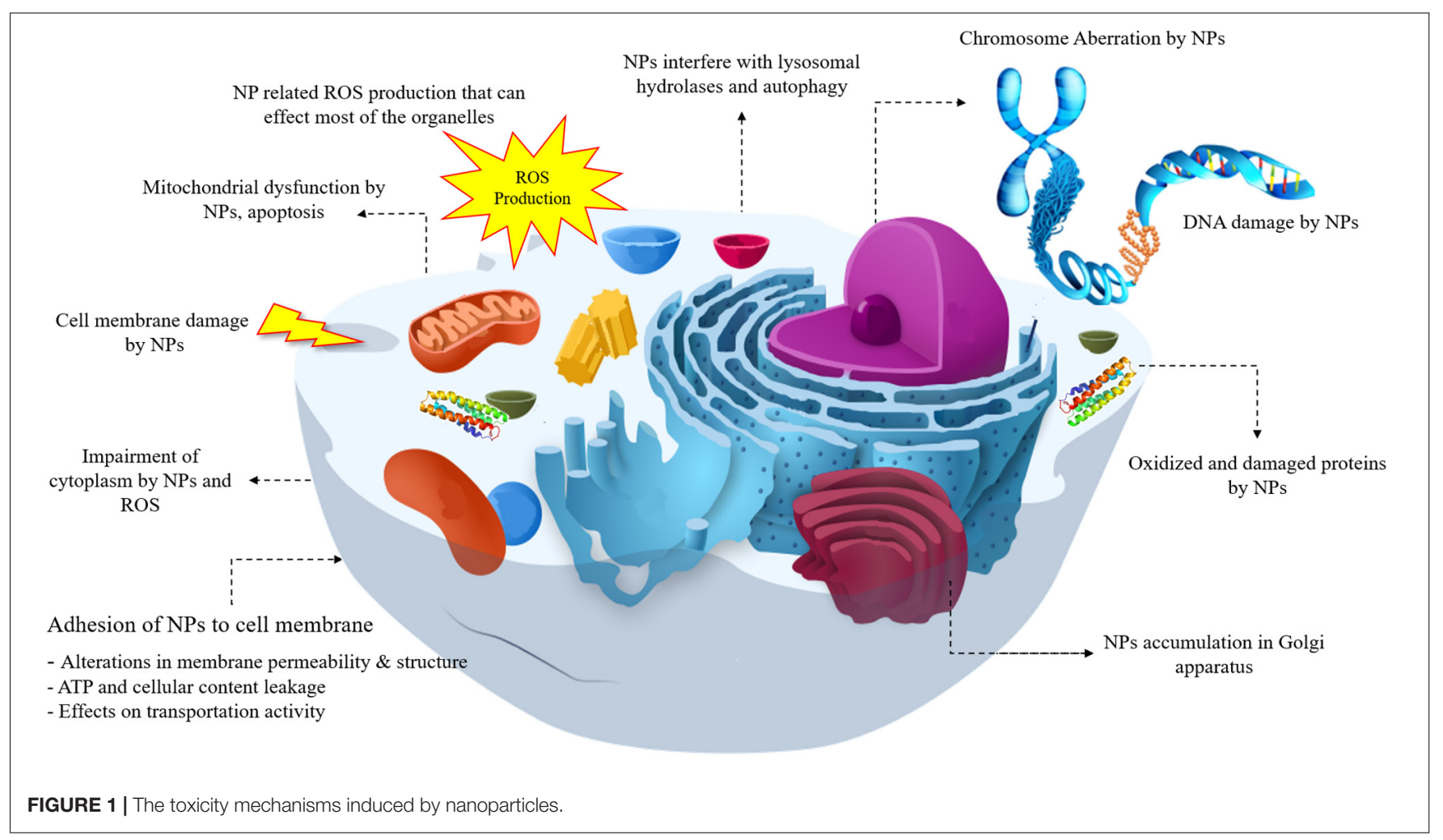

is very hard to determine the exact level of ROS, its cellular levels can be measured through various methods such as fluorogenic and fluorescent probes, also hydrogen peroxide $\left(\mathrm{H}_{2} \mathrm{O}_{2}\right)$, hydroxyl radicals $\left(\mathrm{OH}^{-}\right)$, and peroxyl radicals $\left(\mathrm{ROO}^{-}\right)$ can be estimated by staining methods. In addition, ROS molecules like hydroperoxides (R-OOH) can be quantified by performing the (D-Roms) test through reactive oxygen metabolites derivatives. ROS with a potent chemically reactive characteristic contain oxygen and can be found as superoxides, peroxides, hydroxyl radical, singlet and alpha-oxygen, Figure 2 schematically shows ROS production by NPs, it was believed that some NPs are photosensitizers and they facilitate ROS formation with the light assistance but for the case of tissues which are not exposed to daylight other mechanisms are involved such as 


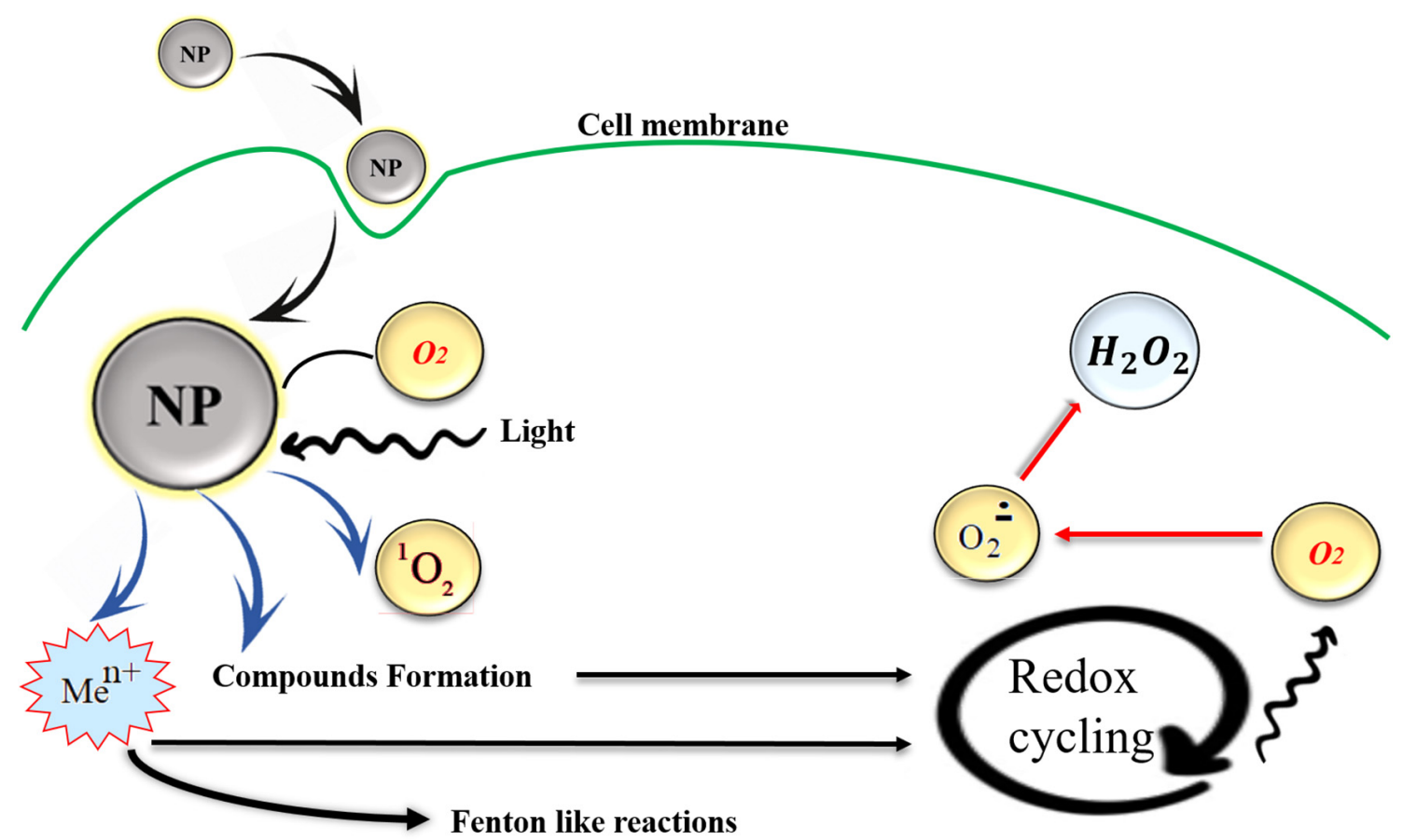

FIGURE 2 | NPs induced ROS production in cells, transition metal ions ( $\left.\mathrm{Me}^{n+}\right)$, or organic compounds may act as initiators of metabolic reactions that generate ROS and they can be released from particle impurities and catalyzing Fenton-type reactions. Also, in some metallic photosensitizer NPs light exposure facilitates the ROS production. Reproduced from Kehrer and Klotz (2015) with permission.

organic material released from combustion derived NPs. Also, transition metal ions can be released from particle impurities and catalyzing Fenton-type reactions, for more details about ROS production see Kehrer and Klotz (2015), Saliani et al. (2016), and Flores-López et al. (2019). The ROS produced as one of the natural byproducts of the normal oxygen metabolism and they affect the cell signaling and homeostasis (Devasagayam et al., 2004). In addition to positive functions of ROS formation in cells, their excess generation by external inputs such as NPs can also lead to some harmful effects like apoptosis (programmed cell death) and may induce damages on RNA or DNA (Wan et al., 2012), lipid peroxidation, amino acids oxidation in proteins and deactivation of enzymes by oxidation of co-factors are other unfavorable results of NPs induced ROS generation (Brooker, 2018). The mechanism of ROS production by metallic NPs depends on particle size, shape, surface area, and chemistry. ROS have a key role in multiple cell functions and its biology. ROS generation plays a crucial role in toxicity issues aroused from NPs application, as well as other related phenomena like cellular signaling fluctuations involved in cell death, proliferation, and differentiation (Dayem et al., 2017).

\section{Cell Damages Through NPs Induced Membrane Perforation}

Some metallic NPs like Au NPs can be used in order to maintain unspecific attachment to the cell membrane and activated the interim and cell membrane permeabilization in a spatial manner (Heinemann et al., 2013). Unfortunately, this characteristic can also cause cell damages, for instance Ag NPs with lower than $10 \mathrm{~nm}$ diameter have a potential to bind with the cell walls in Escherichia coli bacteria and finally leads to cell death (Gogoi et al., 2006). It was observed (Gopinath et al., 2008) that Ag NPs are able to cause cell apoptosis and damage the mitochondrial membrane during cell apoptosis with cell membrane perforation intervention.

\section{Cytoskeleton Components Damage}

Cytoskeleton acts as a footstone of the cell architecture hence the NPs' influence on the cytoskeleton network must be carefully considered. Actin and intermediate filaments, microtubules, and different types of proteins are among the most important components of the cytoskeleton (Ispanixtlahuatl-Meráz et al., 2018). Despite the proven non-toxicity of $\mathrm{TiO}_{2}$ in most studies (Ding et al., 2016; Zhang et al., 2017) it was reported that $\mathrm{TiO}_{2}$ NPs led to actin and tubulin disassembly and some alterations in the cytoskeleton and its proteins (Vuong et al., 2016). $\mathrm{TiO}_{2}$ NPs treated epithelial cell line BEAS-2B confirms the expression alterations in mRNAs and miRNAs which is possibly in relation to the cytoskeleton (Thai et al., 2015). The epithelial cells coculturing and their proteomic analysis indicated that Ag NPs readjust different types of cytokeratins and gelsolin, in contrast to $\alpha$ - and $\beta$-tubulin together with actin which were downregulated, and strong dissolution of Ag confirmed the strong effects of NPs rather than Ag ions (Georgantzopoulou et al., 2016). The $\mathrm{ZnO}$ NPs can be internalized by endosomes and in turn move to lysosomes, also the existence of zinc ions causes cytotoxicity 
and actin rearrangement in cell bundles. Besides, this effected tubulin network by $\mathrm{ZnO}$ NPs can generate wrapped bundles in the periphery of the nucleus and these improper chromosomes and spindles can subsequently distribute all over the cytoplasm region and cause harmful effects (García-Hevia et al., 2016). Xu F. et al. (2013) reported the cytoskeleton component failure like and filamentous actin ( $F$-actin) and the $\beta$-tubulin Ag NPs treated samples, it was also demonstrated that they led to the dramatic reduction in the number of synaptic clusters of the presynaptic vesicle protein synaptophysin, and the postsynaptic receptor density protein PSD-95 and lastly Ag NPs cause mitochondria dysfunction in rat cortical cells.

\section{DNA and Transcription Damage by NPs and Mutagenesis Acceleration}

Application of Co NPs within the non-toxic dose range and their exposure to human lung epithelial cell line A549 demonstrated the ROS generation which finally ended to DNA damage. Subsequently, this DNA damage led to ataxiatelangiectasia mutated (ATM) protein activation and increase the phosphorylation of $\mathrm{p} 53$ and Rad 51 protein expression, $\mathrm{TiO}_{2}$ NPs did not indicate any considerable cytotoxic effects. In addition, Co NPs induced DNA damage is able to actuate various cellular reactions such as apoptosis, cell cycle arrest, and importantly the DNA repair (Wan et al., 2012). The effects of $\mathrm{Cu}$ NPs on transcriptional responses of zebrafish embryos confirmed the up-regulation of genes in the healing of wounds and stimulus reactions but it was seen that the genes which are responsible for phototransduction and metabolisms were acted in downward fashion (Zhang et al., 2018). It seems that $\mathrm{Cu}$ NPs together with $\mathrm{Cu}^{2+}$ ions induce gene transcription damages to Zebrafish embryos (Zhang et al., 2018). The study about the mitotic and meiotic effects of $\mathrm{Cu}$ and $\mathrm{CdS}$ NPs indicated higher degrees of cytotoxicity in $\mathrm{Cu}$ NPs than CdS ones, the mitotic aberrations can be in the result of several phenomena such as (1) DNA depolymerization and sticking of chromosomes bundles, (2) chromosome breakages leading to the generation of rings, bridges, fragments, and micronuclei, (3) prevention of the centromeric division which leads to diplochromosomes formation, (4) spindle apparatus variations which promotes the polyploid cells and laggards. Different mitotic cycles have the potential to initiate the meiotic cell division, NPs inducing aberrations seem to be significant since their consistent changes can cause heritable alterations in the genotype (Kumbhakar et al., 2016).

\section{Mitochondria Damage}

Mitochondria is among the most important organelles of the cells; it chiefly engages in energy supply and differentiation procedure and unfortunately it can be mischievously affected by NPs related toxicity. Mitochondrial permeability transition (PT) occurrence is one of the prime causes of cell death in which a sudden permeability increase in the inner mitochondrial membrane to small size solutes leads to apoptosis, for example, $\mathrm{Au}$ NPs with $1.4 \mathrm{~nm}$ diameter showed to cause oxidative stress leading to mitochondrial PT in which the higher permeability of mitochondrial membrane toward $1.4 \mathrm{~nm} \mathrm{Au} \mathrm{NPs} \mathrm{triggered}$ the cell death by necrosis (Pan et al., 2009). Gallud et al. (2019) also proved the mitochondrial dysfunction in ammoniummodified Au NPs, these cationic Au NPs stimulated autophagy in macrophage-like reporter cells, and cell death can be deteriorated by autophagy inhibition and in general mitochondria-dependent effects of cationic Au NPs induce the quick perish in cells. Yu et al. (2013) reported that ZnO NPs have a capability to affect the mitochondrial membrane potential, also mitochondrial ATP level was significantly diminished in the presence of these ZnO NPs. In addition, interruption of mitochondria, dysfunction, and fall of mitochondrial membrane potential after ZnO NPs treatment to normal skin cells was proven and these NPs adversely influence the mitochondrial network and biogenesis (Yu et al., 2013). Iron-based NPs like $\mathrm{Fe}_{3} \mathrm{O}_{4}$ NPs also can lead to dysfunctions in the mitochondrial activity, increase the ROS production in cells and leads to the draft decrease of ATP level even it can induce autophagy by reduction of cytoplasmic energy (Zhang et al., 2016). These harmful effects are also be seen in $\mathrm{TiO}_{2} \mathrm{NPs}$ and it was reported that $\mathrm{TiO}_{2} \mathrm{NPs}$ can cause severe mitochondrial dysfunction, the increment of ROS levels, reduction of ATP generation, mitochondrial phospholipids and metabolic fluxes (Chen et al., 2018). $\mathrm{TiO}_{2}$ NPs can also affect the dynamic of the mitochondria and leads to its dynamic imbalances and damages in HT22 Cells and it can also activate the mitochondrialrelated apoptosis pathways (Zhao et al., 2019). In the Ag NPs treatment with a diameter of $10 \mathrm{~nm}$ it was seen that these NPs are able to impair mitochondrial function and in turn induce cell dysfunctions (Bressan et al., 2013).

\section{The Effect of NPs on Lysosomes}

Lysosomes are defined as membrane-bound organelles comprising hydrolases that act in the deterioration process of macromolecules transported by various pathways including the endocytic, phagocytic, and autophagic ones (Luzio et al., 2014) and they are considered as acute intracellular organelles controlling the cytotoxicity of nanomaterials (Fröhlich, 2013). Metallic NPs like Ag NPs can be taken up by different cell types and they are able to deposite as agglomerates or aggregates in endosomes or lysosomes of the cytoplasm (Guo et al., 2015; Xu et al., 2015). It was shown (Miyayama and Matsuoka, 2016) that Ag NPs exposure on cells can lead to a reduction of Ag dissolution rate ( $\mathrm{pH}$-dependent behavior) and MT expression which in turn induce damages on pulmonary epithelial cells. The lysosome impairment was also seen in $\mathrm{Fe}_{3} \mathrm{O}_{4}$ NPs (Zhang et al., 2016), metallic NPs can lead to ROS production and its transportation into lysosomes which finally interfering with the lysosomal hydrolases and induce the autophagy process (Halamoda Kenzaoui et al., 2012). It was seen that $\mathrm{TiO}_{2} \mathrm{NPs}$ can be responsible for the increment of lysosomal activities mainly caused by oncogenic transformations (Zhu et al., 2012; Lammel et al., 2019). Also, the strength of lysosomal membrane can be significantly decreased by $\mathrm{TiO}_{2}$ NPs since they could easily get access into digestive cells, in the next step they can accumulate in lysosomes and then released to the alveolar lumen by apocrine extrusion of residual bodies or by holocrine elimination of dead cells (Jimeno-Romero et al., 2016). The Au NPs can also 
decrease the lysosomal functions by alkalization of the lysosomal lumen which in turn induce the autophagosomes accumulation and leads to a reduction of cellular degradative capacity and low efficiency in damaged mitochondria release. In fact, these unstable cellular changes absolutely have an influence on the cell functionality, for instance in Au NPs-marked cells, cell migration and invasion were hindered (Manshian et al., 2018).

\section{PHYSICOCHEMICAL PROPERTIES OF NANOPARTICLES}

The potency of NPs to enter certain organs across specific pathways and their propensity whether to be accumulated in cell organelles or transported to other organelles is affected by both physical and chemical properties of related NPs. In addition, the physicochemical properties of NPs have a great impact on their toxicity since they can change the mechanism of toxicological response and NPs' accumulation, uptake, and translocation (Zoroddu et al., 2014). For instance, the same material with different shapes and sizes can considerably change the response of live tissue and identify the destiny of NPs as a safe or toxic one. The important physicochemical properties related to the cytotoxicity of nanomaterials are morphological features like size, shape, roughness and surface area, uniformity of agglomerates and the aggregate formation, mass of NPs, exact chemical composition, concentration or dose of NPs, surface charge, hydrophilicity, solubility and geometrical properties all can influence the behavior of material (Zoroddu et al., 2014). Figure 3 schematically shows some major physical properties related to the toxicity of metal-based NPs in different categories of dimension, agglomerate condition, shape, and size of NPs and the surface charge, also each of which consisted of various states that finally led to toxicity or safety of NPs.

\section{Size-Dependent Toxicity in Nanoparticles}

The NPs' Size and surface area act as a key factor in its interaction with live tissues, the nanometric size level of NPs are almost in the same range of protein globules ranging from 2 to $10 \mathrm{~nm}$, DNA helix about just two nanometers and cell membrane thickness with $10 \mathrm{~nm}$, so they can easily pass the barriers of cells and enter to cell organelles (Sukhanova et al., 2018). It was shown (De Jong et al., 2008) that the distribution of gold NPs in organs are highly size-dependent, an obvious difference was detected between the distribution of the $10 \mathrm{~nm}$ and the larger particles. Ten $n m$ NPs were found in most of the organs whereas the larger NPs distribution was seen in the limited organs of rats. Actually, gold NPs with $6 \mathrm{~nm}$ size can freely enter to cell nucleus while these NPs in the size range of $10-16 \mathrm{~nm}$ can only be found in cytoplasm and cell membranes which shows the higher toxicity of gold NPs with less than $10 \mathrm{~nm}$ size (Huo et al., 2014). Also, it was reported (Pan et al., 2007) that gold NPs with $15 \mathrm{~nm}$ size is about sixty times less toxic than $1.4 \mathrm{~nm}$ NPs especially for fibroblasts, epithelial cells, macrophages, and melanoma cells. In addition, NPs size can effectively determine and control the interactions between transport and cell defense systems which finally influences the kinetics of NPs distribution and concentration. It is believed that
(Zhang S. et al., 2015). NPs with smaller than $5 \mathrm{~nm}$ diameter generally can defeat cell entrance barriers and they are able to pass through cell membranes by translocation, while the larger NPs get into the cells by phagocytosis and other possible transportation mechanisms. The in vivo experiments (De Jong et al., 2008) confirmed that large NPs can be easily recognized by the immune system and prevents their entrance to the body. The surface area as one of the important factors in NPs cytotoxicity warrants the effective adsorption of NPs on the surface of cell organelles.

\section{The Effect of Nanoparticles' Shape on Toxicity}

Nanoparticles can have a variety of shapes and geometries including spheres, ellipsoids, cylinders, sheets, cubes, spikes, and rods which considerably affect the toxicity. In this relation, the round-shaped NPs are more susceptible to endocytosis than NPs with fiber and tube geometry (Champion and Mitragotri, 2006). Also, it was indicated that (Zhao et al., 2013) plate-like and needle-like NPs induce larger necrosis proportions than other spherical and rod-like NPs since these shapes have more capacity to induce physical damages to cells and live tissues by direct contact. In addition in gold NPs, geometry and shape of the NPs have an impact on the accumulation kinetics and its excretion and only star-like shapes can be stored in the lung, also it was confirmed that shape and geometrical variations do not considerably increase their chance to pass the blood-brain barriers (Talamini et al., 2017).

\section{Chemical Composition}

Along with other critical factors like shape and size, the chemical composition also must be considered with full attention. Inorganic NPs with the same physical condition but distinct chemical composition confirmed to have different toxicological behaviors. One of the examples is the different toxicity of $\mathrm{SiO}_{2}$ and $\mathrm{ZnO}$ NPs with $20 \mathrm{~nm}$ size in which $\mathrm{SiO}_{2}$ induce oxidative stress while $\mathrm{ZnO}$ influences the DNA structure (Yang $\mathrm{H}$. et al., 2009). The induced toxicity related to chemical composition mainly arises from metallic ions' leakage into cells, also some of these metallic NPs are actually has a toxic nature such as As, Pb, $\mathrm{Cd}, \mathrm{Hg}$, and Ag since they can damage the cells (Roane et al., 2009). On the other hand, some metals like Fe and $\mathrm{Zn}$ are useful from the biological aspect of view but they can be harmful at high concentrations and cause toxicity reactions. Most of the mentioned issues can be solved by coating the NPs cores with polymeric shells, silica layers, or new NPs synthesis methods with non-toxic compounds which can lead to enhanced safety and chemical stability against metal ionic leakages and degradations (Soenen et al., 2015).

\section{The Effect of Crystal Structure on the Toxicity of NPs}

It was shown that the different crystal structures of the same NPs can make alterations in the toxicity response. One of the good examples is $\mathrm{TiO}_{2}$ owing to its various crystal structures entitled rutile $\left(\mathrm{TiO}_{2}\right.$ with prism shape), anatase (octahedral crystals), and brookite (orthorhombic crystals). It was reported 


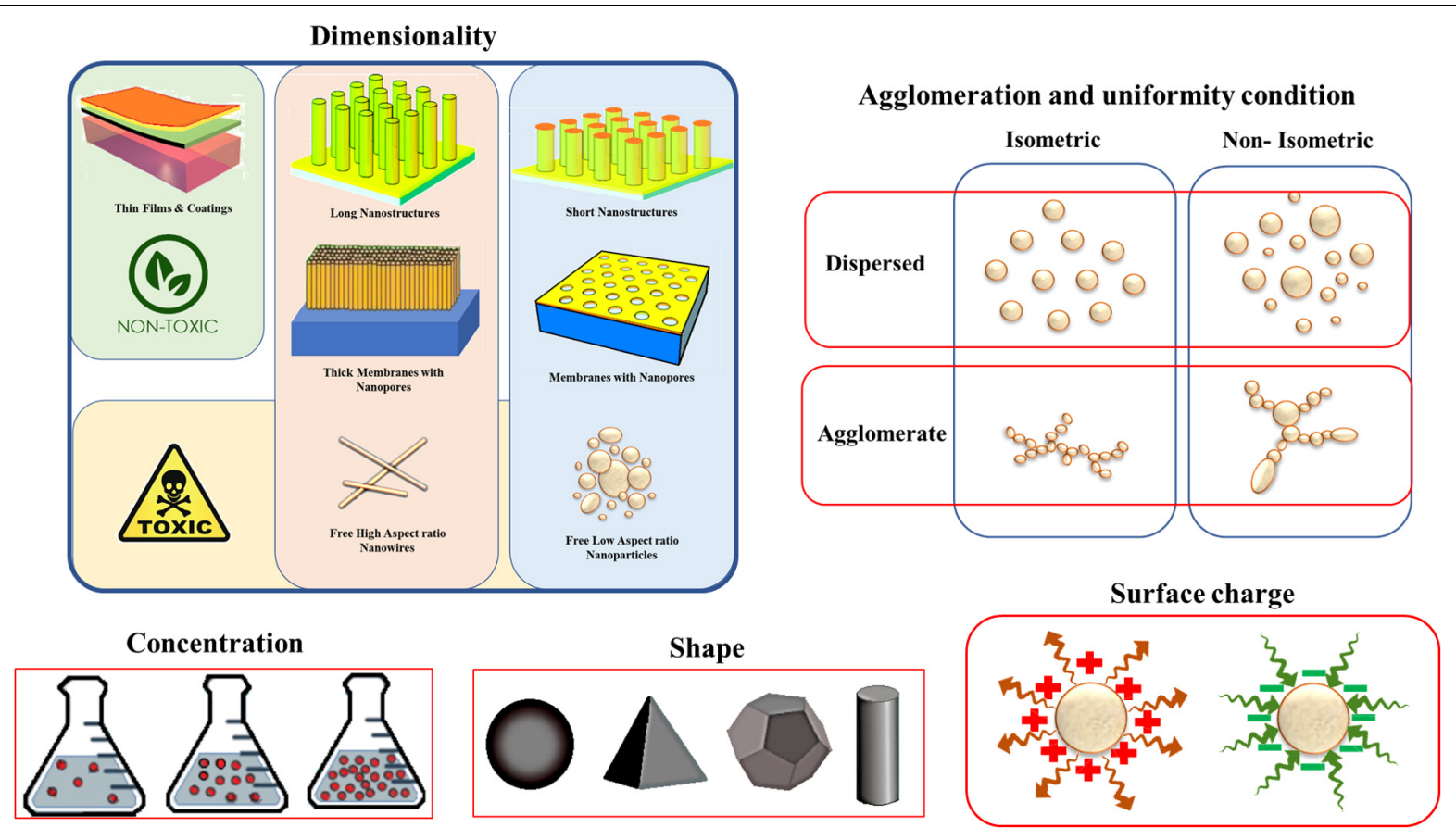

FIGURE 3 | Some physical properties affecting the nanotoxicology of metal-based nanoparticles. Reproduced from Buzea et al. (2007) with permission.

(Gurr et al., 2005) that $200 \mathrm{~nm} \mathrm{TiO}_{2}$ NPs with rutile structure caused hydrogen peroxide and oxidative DNA damage, lipid peroxidation, micronuclei formation, and the signs of abnormal chromosome segregation during mitosis process while in the anatase form there was not any considerable toxicity.

\section{The Effect of Surface Charge on Toxicity}

Ionic charges can affect the interaction between the NPs with cells hence having a great impact on toxicity related mechanisms. The surface charge of NPs can be described by zeta potential which is explained as the potential variation among the mobile dispersion medium and the stationary layer of the dispersion medium that is in attachment with the dispersed particle (Lu and Gao, 2010). Figure 4 schematically shows the zeta potential.

The movement of particles in a fluid cause a net surface charge generation which can be defined by zeta potential hence the constancy of particles dispersion can be determined from zeta potential, NPs with a zeta potential value higher than $130 \mathrm{mV}$ or lower than $230 \mathrm{mV}$ are unlikely to aggregate (Khan, 2020), while NPs with lower zeta potential values are prone to stick to each other, entitled as aggregation in which the particles are firmly bonded, or agglomeration if the particles are weakly bonded due to van der Waal's forces. It was proved that the physical interaction between cellular membrane and NPs is mainly governed by surface charge of NPs and it was also indicated that other toxicity factors like shape and size of NPs have minimal impact on the toxicity of Ag NPs unless the electrostatic barrier between the NPs and cells are overcome. It was shown that positively charged coated Ag NPs are more toxic than that of the negatively charged NPs (El
Badawy et al., 2011). Thevenot et al. (2008) demonstrated that negative charged $\mathrm{COOH}$ treated $\mathrm{TiO}_{2}$ NPs had not an impact on the cell viability because they can easily be absorbed into the cells without any membrane binding. In fact, the positively charged particles are more toxic and the variance surface charge determines the cellular uptake, the positively charged ZnO NPs show increased toxicity values compared to negatively charged NPs (Kim et al., 2014).

\section{The Effect of NPs Solubility}

The metallic NPs that have penetrated the cell is a source for supplying the metal ions and have the potential to constantly release these ions to cytoplasm environment. This metallic ion release is directly dependent on the NPs' dissolution rate (Khan, 2020). Despite the low dissolution, some metallic ions can show a very toxic behavior in physiological mediums, for example, $\mathrm{ZnO}$ NPs with just $10 \mathrm{mg} / \mathrm{L}$ dissolved zinc are highly toxic because of its critical concentration and dose range (Khan, 2020) so they should be used in the safe range and the minimum allowed limit must be considered. Horie et al. (2009) reported that NiO NPs have more activity compared to $\mathrm{NiO}$ fine particles because the NPs can release higher amounts of $\mathrm{Ni}^{2+}$ in the medium while fine particles do not have this capability. In addition, again because of this solubility effect of metallic ions cupric oxide $\mathrm{CuO}$ NPs are considerably more toxic than the same amount of $\mathrm{CuCl}_{2}$ (Karlsson et al., 2008). It was believed that NPs have higher solubility rate than the bulk materials, this finding can only be correct for NPs in the special size condition (less than $100 \mathrm{~nm}$ size) hence particle sizes more than $100 \mathrm{~nm}$ fail to enhance the saturation solubility in the low solubility compounds, even if 


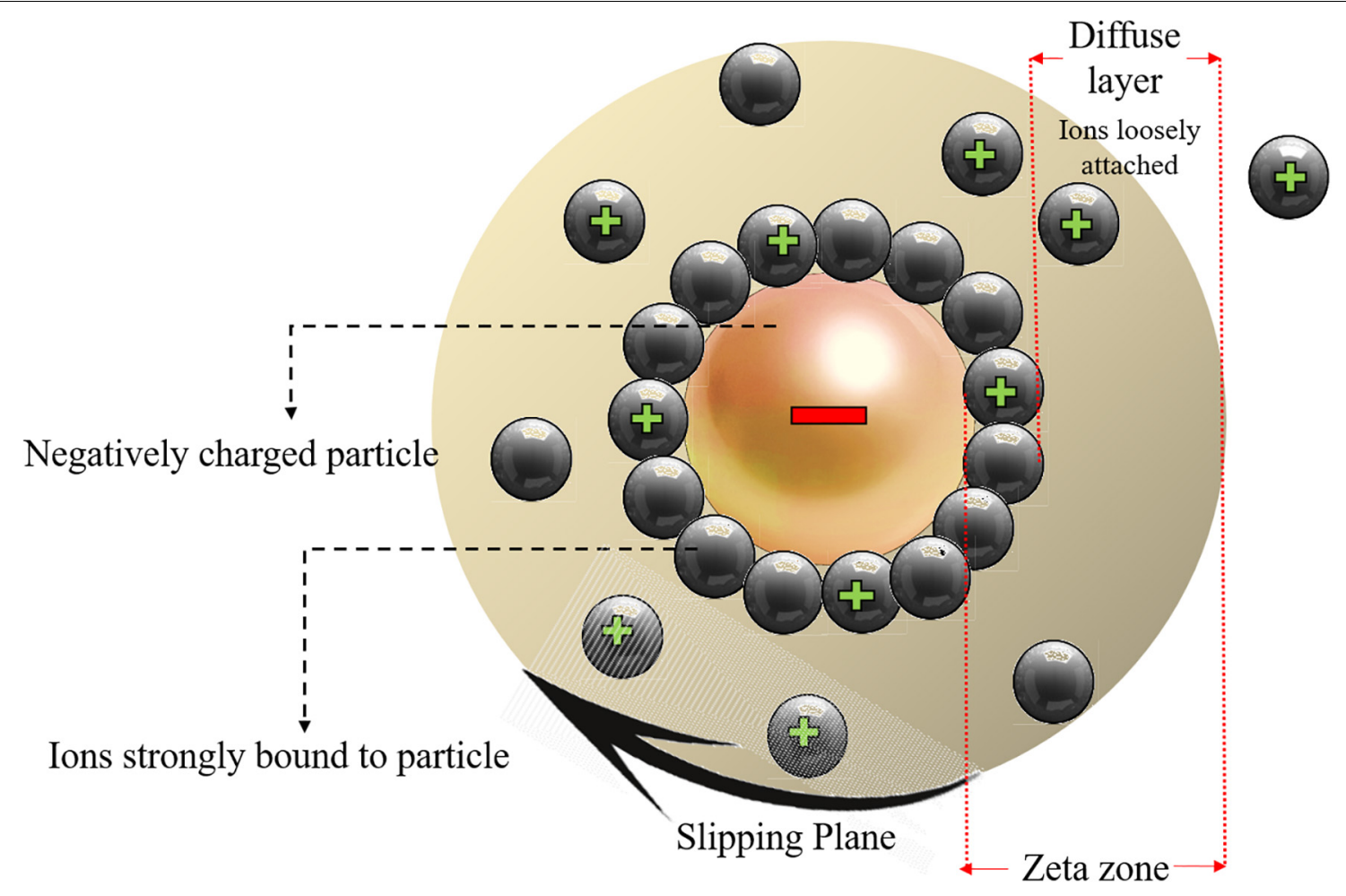

FIGURE 4 | Schematic representation of the zeta potential zone and the electric double layer surrounding the charged nanoparticles. Reproduced from Khan, 2020.

TABLE 2 | Effect of particle size on the solubility behavior and dissolution rate (He, 2009).

\begin{tabular}{lcl}
\hline Size of particle & Solubility ratio $\left(\mathbf{S} / \mathbf{S}_{\infty}\right)^{*}$ & Variations in dissolution rate \\
\hline $10 \mu \mathrm{m}$ & 1 & No considerable effect \\
$1 \mu \mathrm{m}$ & 1.01 & 10 -fold increase \\
$100 \mathrm{~nm}$ & 1.13 & 113 - fold increase \\
$10 \mathrm{~nm}$ & 3.32 & 3320 -fold increase \\
\hline
\end{tabular}

$\left(S / S_{\infty}\right)^{*}$ : the ratio of solid solubility to be dissolved with that of the substance having infinitely large solubility.

the rate of dissolution is increased, Table 2 shows this situation in more details.

\section{TOXICITY OF COMMON METALLIC AND METAL OXIDE NPS}

The toxicity phenomenon is a very complicated issue that is dependent on lots of physicochemical parameters, hence different metallic NPs with their special nature would have various toxicity mechanisms and indicate alterations in toxicity amount. It was known that usually as the atomic number of the element increases, cytotoxicity increases (Huang et al., 2017), possibly due to band-gap energy. Also, it was shown that different materials activate certain toxicity mechanisms. In this relation, the present study discusses the involved nanotoxicology mechanisms of common metallic and metal oxide NPs including Ti, Ag, Au, Zn, and $\mathrm{Cu}$, and their effects on biological environments.

\section{Titanium Dioxide $\mathrm{TiO}_{2}$ NPs Toxicity; in vitro and in vivo}

Titanium oxide NPs are among the most manufactured NPs with approximately 10,000 tons yearly production, owing to its unique properties such as suitable strength and Young's modulus (Ansarian et al., 2019; Attarilar et al., 2020), biocompatibility (Attarilar et al., 2019), corrosion resistance (Gode et al., 2015), solubility properties, surface structure, and the related aggregation manner so it has a lot of applications in industry as listed in Table 1. This wide use of $\mathrm{TiO}_{2}$ NPs and its post disposal in the environment may arise the health and ecosystem issues hence its impact on live organisms in vitro and in vivo must be studied and considered.

The impact of $\mathrm{TiO}_{2}$ NPs' shape on toxicity was examined in BEAS-2B cells, the shape of NPs was selected as bipyramids, rods, and platelets. It was seen that the rod-shaped NPs induced the most amount of toxicity, but in the platelets the genotoxicity and oxidative DNA damage were seen and their accumulation was higher than the rod and bipyramid-shaped NPs (Gea et al., 2019). It seems that among different crystal structures of $\mathrm{TiO}_{2}$, the anatase form has more toxicity. De Matteis et al. (2016) indicated that titanium ions are more prone to release in anatase rather than rutile form, also anatase form leads to more ROS production in MCF-7 cell line. Consequently, anatase influences the mitochondrial membrane and is more prone to activate the 
apoptosis pathway. $\mathrm{TiO}_{2} \mathrm{NPs}$ treated Caco-2 cell indicated the affected intestinal epithelium layer after $24 \mathrm{~h}$ exposure and the cell viability shows the $13 \%$ reduction compared to the control sample (Pedata et al., 2019). Transmission electron microscope (TEM) observations showed that $\mathrm{TiO}_{2}$ NPs were selectively accumulated in Caco-2 monolayers, as indicated in Figure 5. Also, it was proved that titanium ions have the potential to trigger the production of the pro-inflammatory cytokines and led to some toxic effects on the intestinal epithelium layer (Pedata et al., 2019). Experiments on the A549 cell line (human lung epithelial cells) confirmed the significant cytotoxic effects of citrate-coated $\mathrm{TiO}_{2}$ NPs also the DNA damage experiments by comet assay indicated the increasing genotoxic effects in these citrate coated NPs. In fact, variation in the physicochemical properties of NPs by variation in the surface of coating affected the NPs' toxicity (Stoccoro et al., 2017).

An in vivo study about $\mathrm{TiO}_{2}$ NPs was done by Fabian et al. (2008), $\mathrm{TiO}_{2}$ NPs (<100 nm) were injected to Wistar rats. They did not find any sign of $\mathrm{TiO}_{2} \mathrm{NPs}$ accumulation in brain and lymph nodes, blood cells, and plasma, the most bioaccumulation of NPs was seen in the liver and lower values of NPs were detected in the kidney, lung, and spleen. $\mathrm{TiO}_{2}$ NPs injection into rats at a moderate dose of $20 \mathrm{mg} / \mathrm{kg}$ for 20 days had some effects on liver including congestion, prominent vasodilatation, and vacuolization that finally led to liver dysfunction, $\mathrm{TiO}_{2}$ NPs injection at high doses $(1387 \mathrm{mg} / \mathrm{kg}$ body weight) led to mortality of rats after 2 days of injection whereas the low dose injections (in the range of $10 \mathrm{mg} / \mathrm{kg}$ body weight) induced toxicity related signs such as decreased water and food consumption, increased number of white blood cells (Ben Younes et al., 2015). Xu J. et al. (2013) showed that $\mathrm{TiO}_{2}$ NPs treatment induced some damages in the kidney, lung, brain, spleen, and liver of rats but no considerable pathological effects were detected in rats' heart. In another study, the rutile $\mathrm{TiO}_{2}$ NPs treated rats indicated normal external lung morphology while $\mathrm{TiO}_{2}$ NPs in crystalline form with $80 \%$ anatase and $20 \%$ rutile content showed pulmonary toxicity (Abdelgied et al., 2019). Briefly, it can be said that shape, higher dose, crystalline structure, and phases have the potential to cause toxicity in both in vitro and in vivo studies hence

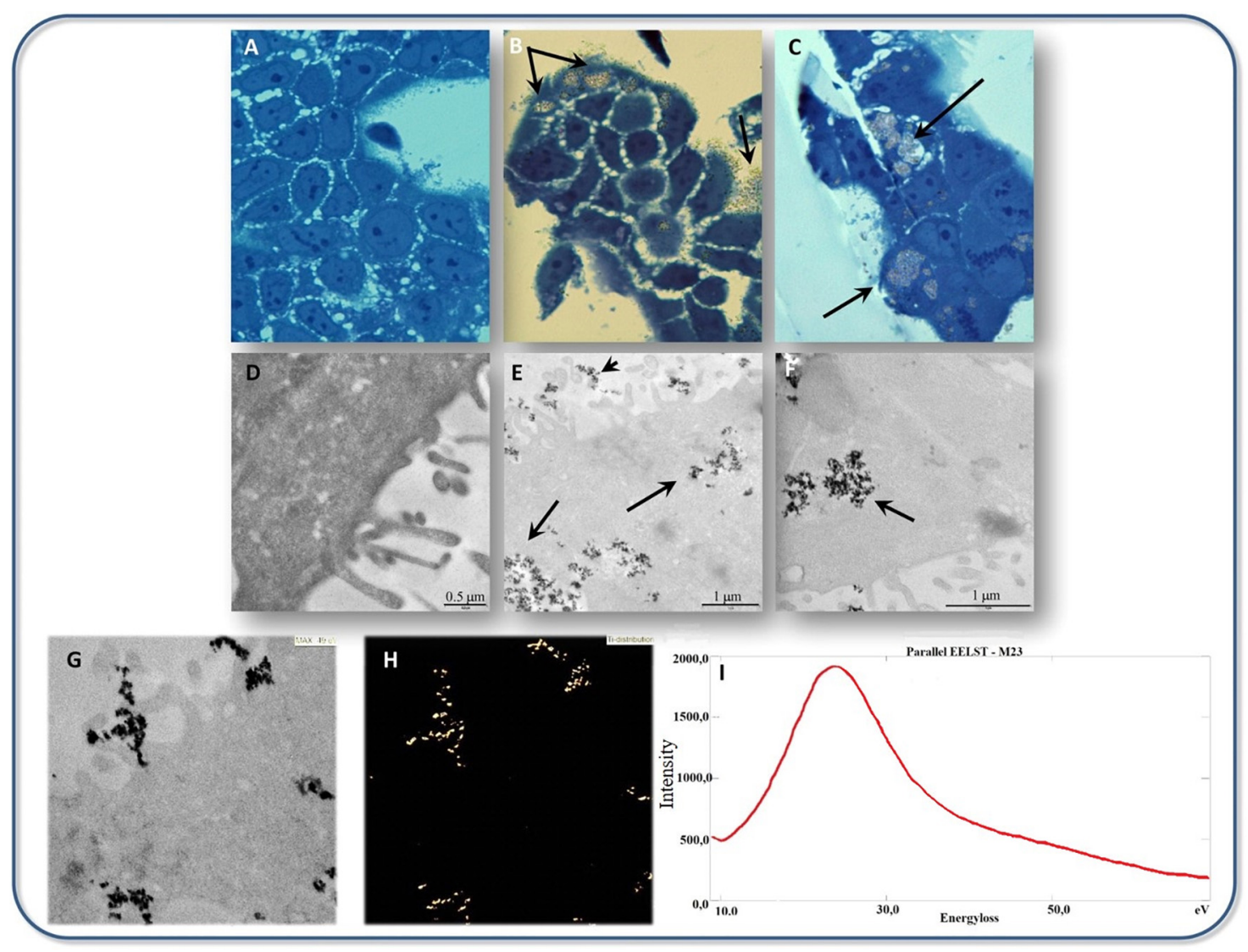

FIGURE 5 | Transmission electron microscope micrographs of $\mathrm{TiO}_{2}$ NPs interaction with cultured Caco-2 cells, (A-C) Bright field optical microscopy analysis of Caco-2 cells cultured (A) without, (B,C) with $500 \mu \mathrm{g} / \mathrm{mL} \mathrm{TiO}_{2}$ NPs. Black arrows indicate $\mathrm{TiO}_{2} \mathrm{NPs}$ accumulation observable on the surface of cells as well as in the cytoplasm. (D-F) TEM analysis of Caco-2 cells cultured with (E,F) or without (D) $500 \mu \mathrm{g} / \mathrm{mL} \mathrm{TiO}_{2} \mathrm{NPs}$. Black arrows in (E,F) indicate TiO 2 NPs accumulation. (G,H) The ultrastructural appearance of Caco-2 cells cultured with $500 \mu \mathrm{g} / \mathrm{mL} \mathrm{TiO}_{2} \mathrm{NPs}(\mathbf{G})$ with the respective map of Ti localization (ESI analysis) is shown in panel (H). (I) Electron energy loss spectrum (EELS), withdrawn from the same sample regions of $(\mathbf{G}, \mathbf{H})$, is shown. A peak at 25 eV compatible with the TiM 2,3 edge electron energy loss was detected. Adapted from Pedata et al. (2019) with permission from Elsevier. 
the careful control of $\mathrm{TiO}_{2}$ NPs would be led to more safe utilization of these NPs.

\section{Silver Nanoparticles and Their Toxicity}

Silver as a noble metal in nanoparticle condition is the most widespread antibacterial agent, also Ag salts are utilized as agents for the treatment of different bacterial infections. Consequently,
Ag NPs are vastly utilized as bactericides due to its attainment in antibiotic resistance by various bacteria (Sintubin et al., 2012). Ag NPs have the potential to attach to the cell membrane of bacteria or fungi and induce damages on cell membrane structure, intracellular components leakage and in the end cell death (Yamanaka et al., 2005), they can also produce free radicals and cause oxidative stress (Park et al., 2009). Ag NPs are able to

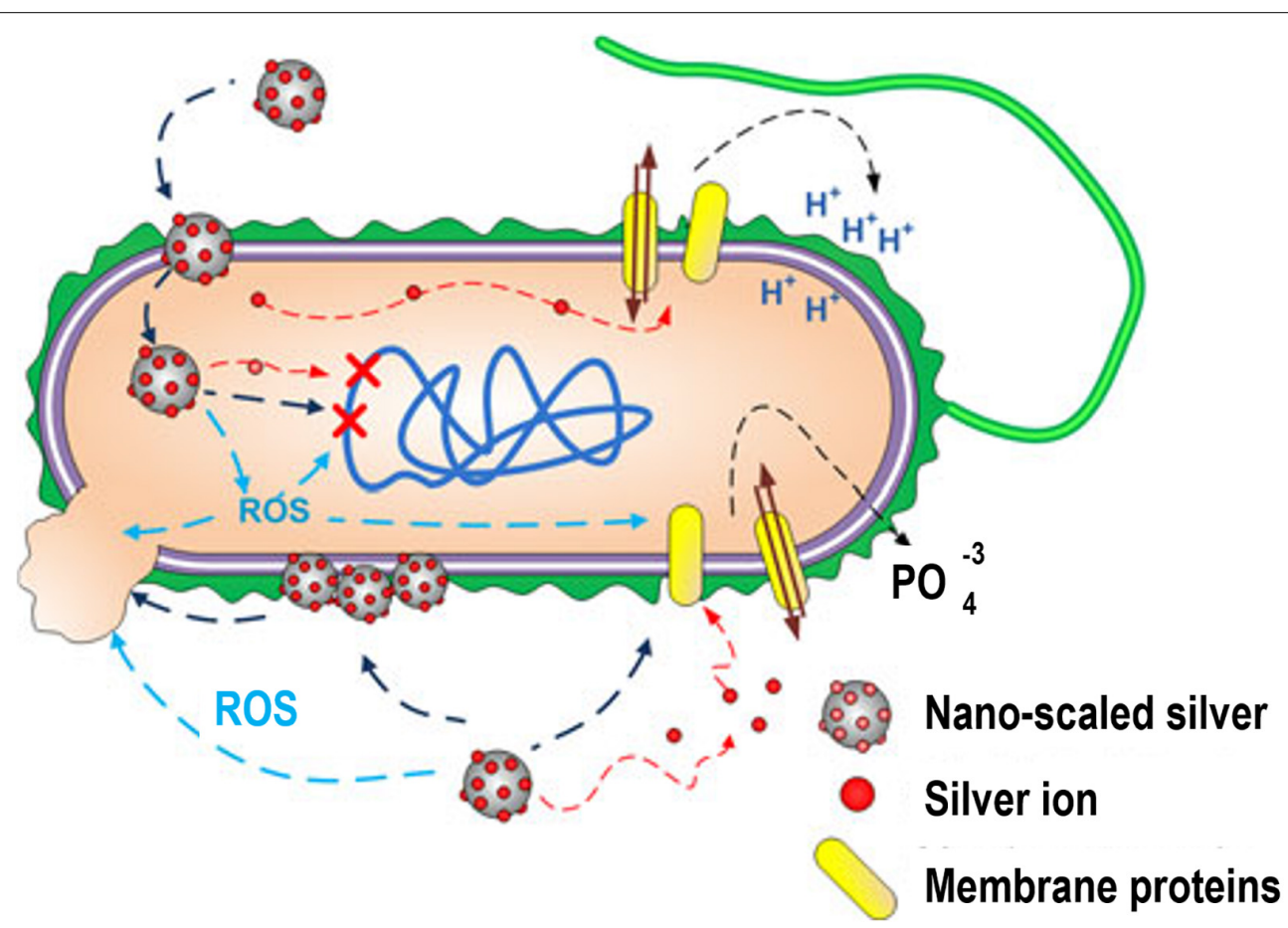

FIGURE 6 | Ag NPs interaction with bacterial cells. Ag NPs can induce (1) Ag ions leakage and ROS generation, (2) membrane proteins dysfunction, (3) accumulation in cell membrane influencing the membrane permeability, (4) DNA damage. Adapted from Marambio-Jones and Hoek (2010) with permission.
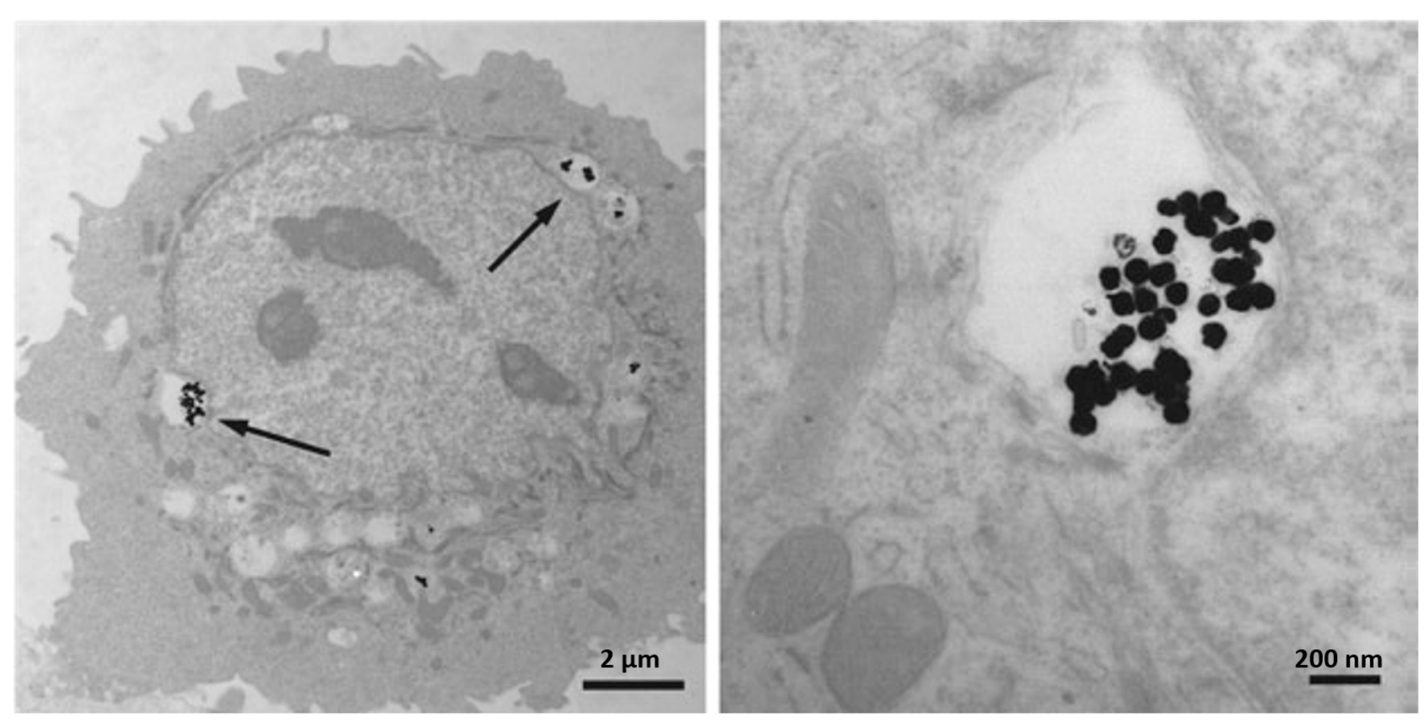

FIGURE 7 | Transmission electron micrographs depicting Ag NPs uptake into HEK cells. (A) 80 nm Ag NPs within cytoplasmic vacuoles of a HEK; (B) higher magnification of the (A). Arrows point to Ag NPs. Adapted from Deyhle et al. (2012). 
construct destructive binding with genomic DNA and prevent the direct replication (Yang W. et al., 2009), it can also decrease the activity of enzymes and other proteins in the transcription stage (Yamanaka et al., 2005), Figure 6 shows Ag NPs interaction with bacterial cells (Marambio-Jones and Hoek, 2010).

The dose of Ag NPs utilization for inhibition of microbial growth must be kept under the range of human cell cytotoxicity. In vitro cell studies indicated the dependence of cytotoxicity on the size of Ag NPs and related ROS generation in different cell lines including fibrosarcoma, skin carcinoma, fibroblast, glioblastoma, hepatoma, alveolar, and keratinocyte (Wijnhoven et al., 2009; Samberg et al., 2010). In addition to size, the cytotoxicity and genotoxicity of Ag NPs are associated with its coating, concentration, exposure time, environmental factors, particle aggregation, surface oxidation to form silver oxides, etc. (Akter et al., 2018). Both Ag and its oxides have the potential to release $\mathrm{Ag}^{+}$and $\mathrm{Ag}^{0}$ into media which consequently results in ionic Ag concentration in the environmental media and causes some degree of dysfunctions in mitochondria (Reidy et al., 2013). Subsequently, the interaction of Ag NPs with cell membrane proteins can lead to activation of signaling pathways for ROS generation and eventually cause proteins and nucleic acids destruction because of the potent affinity of silver for sulfur, at the end all of these events led to apoptosis and reductions in cell proliferation (Haase et al., 2012). Figure 7 shows the TEM images indicating AG NPs uptake in HEK cells.

There are some limited in vivo studies about the $\mathrm{Ag}$ NPs toxicity, it was shown that these NPs induced some harmful impacts on reproduction, malformations, and various morphological destructions in different animal models (Zhang X.F. et al., 2015). Drinking Ag NPs contained water to rats for 1-2 weeks duration, indicated Ag NPs distribution in musculus soleus, cerebellum, spleen, duodenum, and myocardial muscle (Pelkonen et al., 2003), also a dose-dependent Ag NPs accumulation in the liver of rats was reported (Kim et al., 2008). Prolonged intake of Ag NPs in the salt form with low concentrations led to fatty degeneration in the liver and kidneys together with variations in blood cells (Wijnhoven et al., 2009).
Intravenous Ag NPs injection in rats showed $40 \mathrm{mg} / \mathrm{kg}$ dose (higher than $20 \mathrm{mg} / \mathrm{kg}$ dose values considered as toxic in rat models) can cause a considerable increase in liver enzymes whereas ROS increasing was detected in blood serum also TEM micrographs indicated the particle deposition in the liver and kidney of rats (Tiwari et al., 2011).

\section{Gold Nanoparticles and Their Toxicity}

Gold ( $\mathrm{Au}$ ) NPs are also having a place between widespread NPs since they can be used in order to evaluate the cellular uptake and tissue distribution of particles, due to their easy to detect nature by electron microscopy and it has other applications as listed in Table 1. In addition, gold salts such as sodium gold thiomalate are utilized as decisive disease-modifying antirheumatic agents (Fadeel and Garcia-Bennett, 2010) but its long-term accumulation in the body can cause cytotoxic effects.

It was confirmed that the cellular response to Au NPs is sizedependent. For instance, $1.4 \mathrm{~nm} \mathrm{Au} \mathrm{NPs} \mathrm{is} \mathrm{among} \mathrm{the} \mathrm{most}$ toxic conditions of these NPs and results in rapid cell death by necrosis (Pan et al., 2007) while it seems to be non-toxic in $15 \mathrm{~nm}$ condition (Chen et al., 2009). In vitro studies about the Au NPs (35 nm) indicated its low toxicity for murine RAW macrophages with no considerable cell functionality blockage (Shukla et al., 2005). Coradeghini et al. (2013) investigated the effect of 5$20 \mathrm{~nm} \mathrm{Au} \mathrm{NPs} \mathrm{on} \mathrm{human} \mathrm{fetal} \mathrm{lung} \mathrm{fibroblast} \mathrm{cells} \mathrm{(MRC-5)}$ and no considerable effect on the viability of MRC-5 cells was detected but cell proliferation was inhibited. Also, the oxidative DNA damage was confirmed due to NPs' destructive effects on DNA. The smaller the Au NPs, the higher its tendency to induce toxicity since smaller NPs can easily bind on cellular surfaces. For example, Au NPs with $1.4 \mathrm{~nm}$ diameter are capable to bind with DNA and influence genes (mutation) compared to their larger counterparts (Yah, 2013). The dose of NPs has a crucial role in cytotoxicity, for example, Au NPs with a size range of 2$40 \mathrm{~nm}$ are biologically safe to MRC- 5 cells but in exceeded dosage range (10 ppm dosage) apoptosis and up-regulated expression of pro-inflammatory genes and tumor necrosis was reported (Yen et al., 2009).
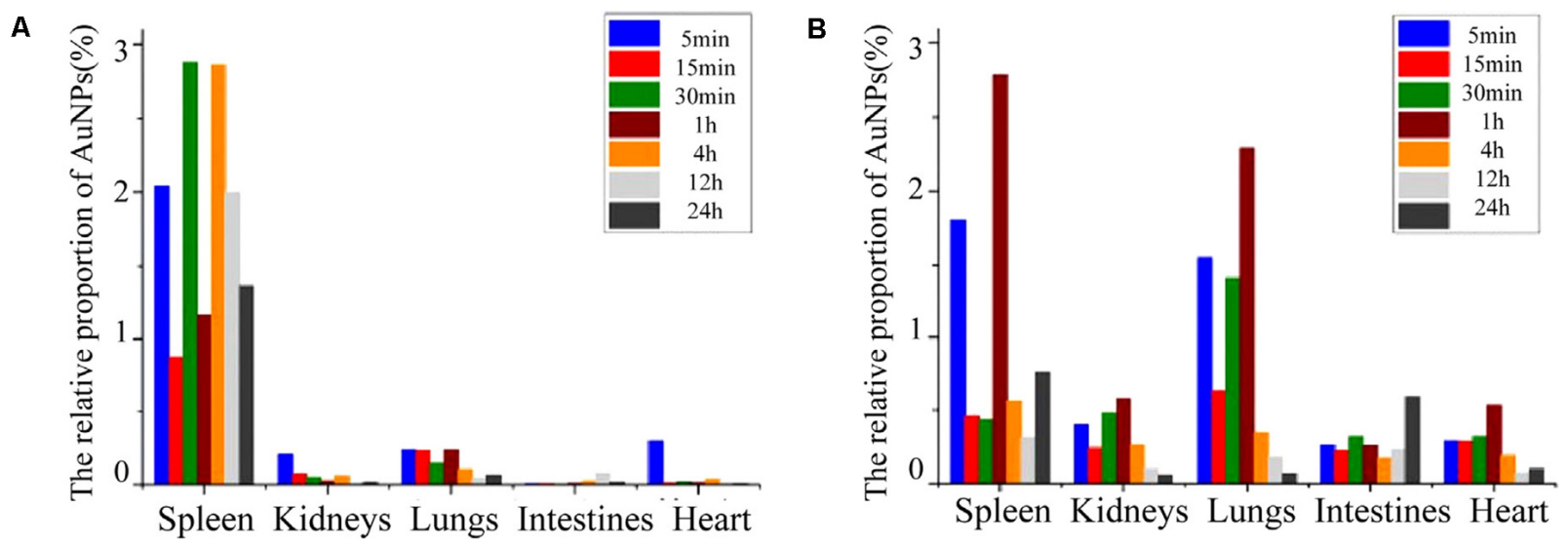

FIGURE 8 | The relative distribution proportion of Au NPs in the spleen, kidneys, lungs, intestines, and heart of SD rats at 5, 15, 30 min, 1, 4, 12, and 24 h after IVI (A), and after ISI in the tarsal tunnel (B). Adapted from Shi et al. (2016) and Jia et al. (2017) with permission. 
The Au NPs (5 nm) can preferentially bind to specified growth factors like vascular endothelial growth factor (VEGF) perhaps by cysteine residues of the heparin-binding domain and cause the inhibition of angiogenesis in a mouse model (Fadeel and Garcia-Bennett, 2010). Intravenous implementation of $\mathrm{Au}$ NPs (18 nm diameter) in rats showed that NPs were selectively accumulated within the liver and spleen, while NPs with $1 \mathrm{~nm}$ size were secreted in urine and feces. In addition, $3.7 \%$ of $1 \mathrm{~nm}$ sized particles remained in the blood at the first $24 \mathrm{~h}$ hence $\mathrm{Au}$ NPs interaction is size-dependent (Semmler-Behnke et al., 2008). Sonavane et al. (2008) studied the tissue distribution of $\mathrm{Au}$ NPs in rats, NPs intravenous exposure confirmed the highest accumulation in the liver and with lower amounts in the lung, kidney, and spleen. The smaller NPs with 15 and $50 \mathrm{~nm}$ size even can be found in the brain which indicates its ability to pass the blood-brain barrier hence they have the potential to get into the brain through neuronal transport. Au NPs with $20 \mathrm{~nm}$ size entry via inhalation can concentrate in the olfactory bulb of rats ( $\mathrm{Yu}$ et al., 2007). Figure 8 shows the relative distribution proportion of the $\mathrm{Au}$ NPs in the various organs of rats including spleen, kidneys, lungs, intestines, and heart at different time durations.

Berce et al. (2016) investigated the bone marrow toxicity of $\mathrm{Au}$ NPs in rats, it was shown that Au NPs accumulated in the hematopoietic bone tissue and unfortunately resulting in severe side effects such as leucopoiesis and megakaryopoiesis and also increased levels of white blood cell and platelet were found in $\mathrm{Au}$
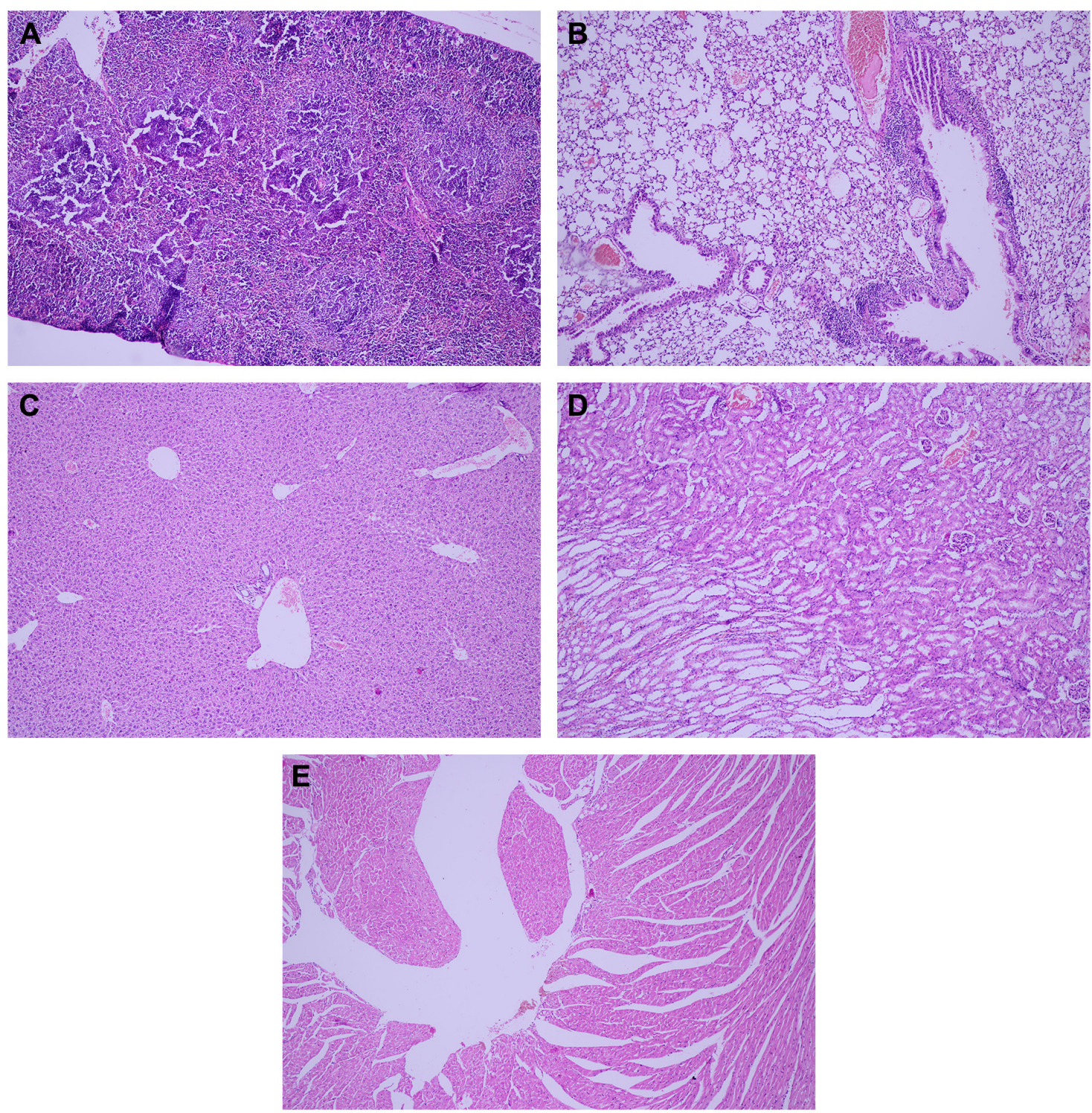

FIGURE 9 | The pathology examination of the Au NPs treated rat organs, in 1,100 $\mu \mathrm{g} / \mathrm{kg}$ dosage the pathology examination of the organs showed no degenerative, inflammatory, vascular, necrotic, or apoptotic lesions over the spleen (A), lung (B), liver (C), kidney (D), and heart (E). Adapted from Berce et al. (2016) with permission from Dove Medical Press. 
NPs treated rats compared to control ones, indicating its toxic effects. Figure 9 shows the pathology examination of the $\mathrm{Au}$ NPs treated rat organs as it was seen in the $1,100 \mu \mathrm{g} / \mathrm{kg}$ dosage no considerable sign of degenerative, inflammatory, vascular, necrotic, or apoptotic lesions was detected. While the pathology experiments through bone marrow and sternum in Figure 10 showed that the mice which got the daily iv Tween ${ }^{\circledR} 20$-GNPs had increased megakaryopoiesis as opposed to the control group. Figures 10A,B shows the increased megakaryopoiesis as opposed to the control group in Figures 10C,D, but no bone marrow fibrosis was detected.

\section{Zinc and Zinc Oxide Cytotoxicity}

The zinc and zinc oxides were listed as safe substances in a US Food and Drug Administration (USFDA) (U.S. Food Drug Administration, 2019), while in the NPs condition it can induce toxicity into the surrounding environment. In vitro toxicity investigations of $\mathrm{ZnO} \mathrm{NPs}$ in the size range of $40-48 \mathrm{~nm}$ in exposure to Chlorella Vulgaris indicated the reduction in viability, superoxide dismutase (SOD), and glutathione (GSH) and also increment of lactate dehydrogenase (LDH) (Suman et al., 2015). This finding indicates the considerable impact of ROS production in the cytotoxicity of ZnO NPs. Together with shape and concentration, the surface charge of $\mathrm{ZnO}$ NPs has a key role in its toxicity. It was believed that the positively charged NPs induce more toxicity and it can affect the cellular uptake and intracellular location (Asati et al., 2010; De Angelis et al., 2013). Kim et al. (2014) also proved the higher cytotoxicity of positively charged $\mathrm{ZnO} \mathrm{NPs}$ in comparison to the negatively charged ones. In addition, genotoxicity and DNA damage was seen in $\mathrm{ZnO}$ treated MRC5 lung cells along with the high secretion of extracellular $\mathrm{LDH}$ and reduction in cell viability ( $\mathrm{Ng}$ et al., 2017). Also, the $\mathrm{Zn}^{2+}$ release in $\mathrm{ZnO}$ NPs could lead to free radical emissions from the NPs surface and resulted in metabolic disbalance and fluctuation in ionic state of cells related to the deterrence of ion transport and defects in ionic homeostasis (Namvar et al., 2015; Suman et al., 2015).

ZnO NPs treatment of rats with $300 \mathrm{mg} / \mathrm{kg}$ dose showed the NPs concentration in the liver which led to cell trauma also a considerable DNA lesion in the liver was seen which resulting in oxidative stress caused DNA damage (Sharma et al., 2012), Figure 11 shows the pathological alterations in the liver and kidney of rats, treated with ZnO NPs for 14 consecutive days and also the control samples. The intraperitoneal injection with 50$200 \mathrm{mg}$ of $\mathrm{ZnO} \mathrm{NPs} / \mathrm{kg}$ body dosage in Wistar rats indicated the dose-dependent toxicity behavior of ZnO NPs with considerable ROS generation also a major enhancement in liver enzymes at the concentration of $100 \mathrm{mg} / \mathrm{kg}$ animal body weight was
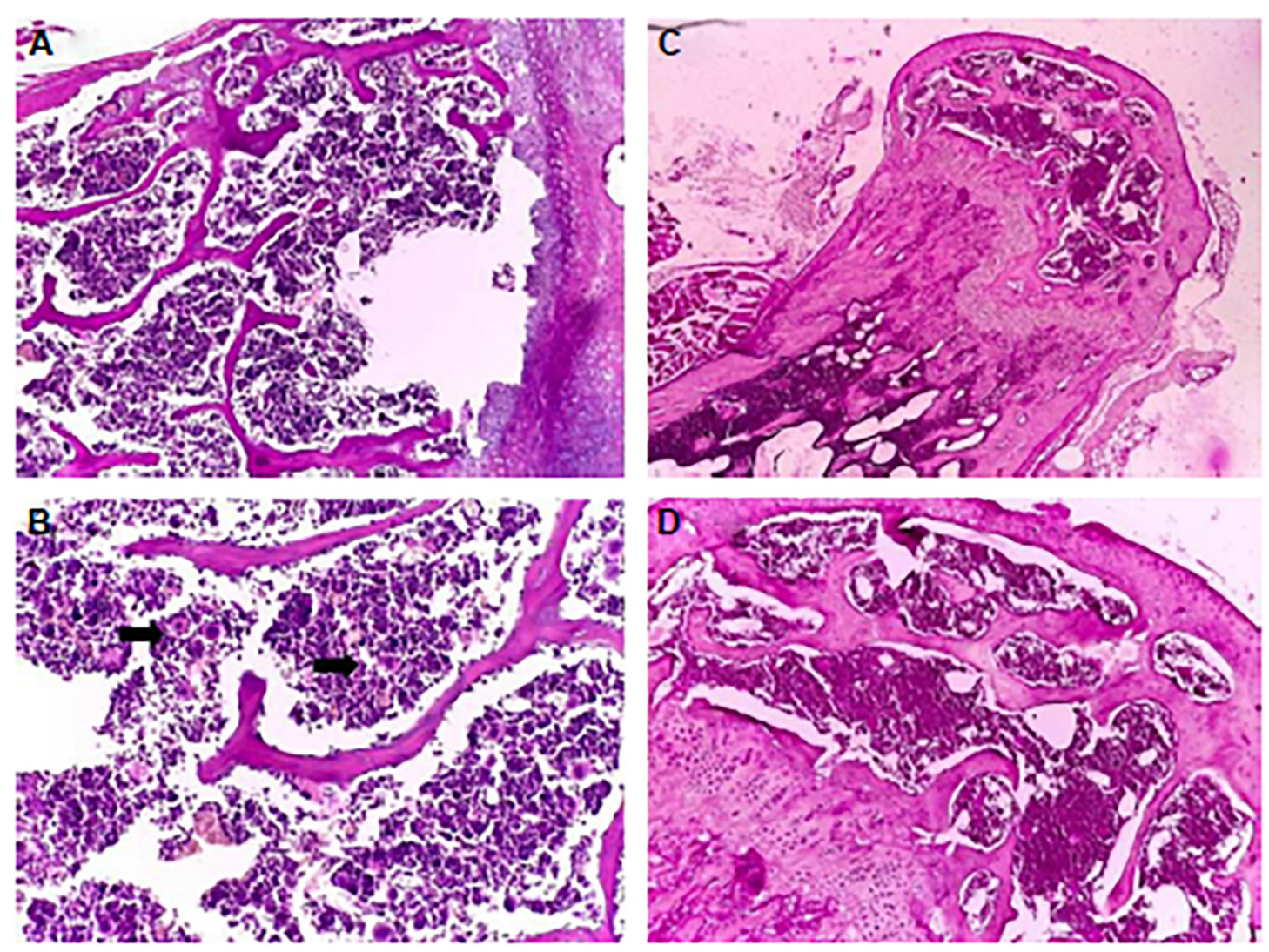

FIGURE 10 | The pathology experiment of the bone marrow of the mice treated with Tween 20-GNPs (A,B) and of the control group (C,D). In (A,C) the magnification was $\times 4$, and in $(\mathbf{B}, \mathbf{D}) \times 20$ magnification was used. The black arrows indicate the megakaryocytes. Adapted from Berce et al. (2016) with permission from Dove Medical Press. 
reported (Abbasalipourkabir et al., 2015). ZnO NPs exposed liver tissue of animals indicated inflammation, increased congestion, chromatin condensation, and apoptosis, the tissue distribution analysis of $\mathrm{ZnO}$ NPs confirmed the increasing zinc dosages in the liver, large intestine, small intestine, and feces and some degree of hyperkeratosis and papillomatosis were detected in the skin (Ryu et al., 2014). Hence, $\mathrm{ZnO}$ NPs have toxic effects in both in vitro and in vivo studies including cytotoxicity, oxidative stress, and genotoxicity thus exposure to $\mathrm{ZnO}$ NPs should be considered and controlled precisely.

\section{Toxicity of Copper and Copper Oxide NPs}

Copper oxide $(\mathrm{CuO})$ NPs have special characteristics like spin dynamics, high-temperature superconductivity, and electron correlation effects (El-Trass et al., 2012). Copper can be found in two ionic conditions $\mathrm{Cu}^{1+}$ and $\mathrm{Cu}^{2+}$ hence it can be interacting with biochemical reactions both as a reducing or oxidizing agent, nevertheless, it is not favorable from the toxicity aspect since copper ions are capable to induce oxidative stress (Valko et al., 2005), genotoxicity (Adeyemi et al., 2020), and free radical production (Fahmy et al., 2020).

In vitro examinations on the toxicity of $\mathrm{CuO}$ NPs on human breast cancer MCF-7 cells had shown some morphological changes in cells, also autophagic vacuoles were detected and the cell cycle arrest caused apoptosis (Laha et al., 2014). The study about lung epithelial cells treated with $\mathrm{CuO}$ NPs with $9.2 \mathrm{~nm}$ size with at various concentrations indicated that these NPs led to a reduction of cell cytotoxicity and increased level of dosedependent oxidative stress (Jing et al., 2015). The effect of size and shapes on the toxicity of $\mathrm{CuO}$ NPs was investigated by Thit et al. (2015), two sizes of $\mathrm{CuO}$ NPs with $6 \mathrm{~nm}$ and $100 \mathrm{~nm}$ larger polydispersed $\mathrm{CuO}$ NPs, also microparticles and $\mathrm{Cu}$ ions were examined in epithelial kidney cells. The most toxic state belongs to the polydispersed $\mathrm{CuO}$ NPs and they induced a considerable increment in intracellular ROS generation, DNA damage, and cell death, Figure 12 schematically presents the in vitro toxicity model of CuO NPs.

In vivo studies in mouse models have shown that $\mathrm{CuO}$ NPs induced obviously epigenetic changes (Lu et al., 2016). Oral exposure of $\mathrm{CuO}$ NPs into rats showed the NP uptake in spleen,
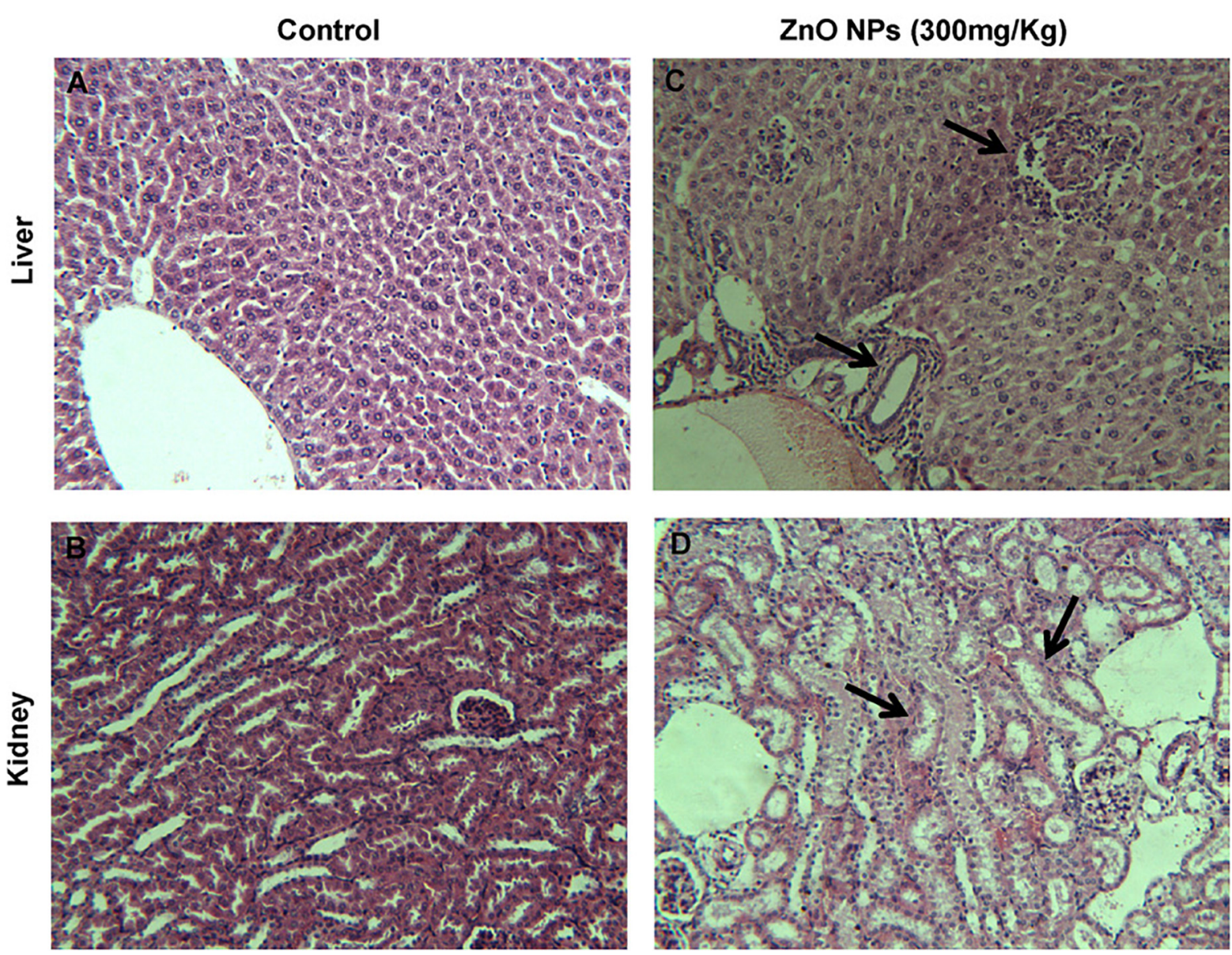

FIGURE 11 | Histopathology of liver and kidney tissues in mice, ZnO NPs treated for 14 consecutive days. (A,B) Control group showing normal liver and kidney, (C,D) pathological alterations in the liver and kidney of ZnO NPs (300 mg/kg) treated group (indicated by arrow); magnification (200x). Adapted from Sharma et al. (2012) with permission. 


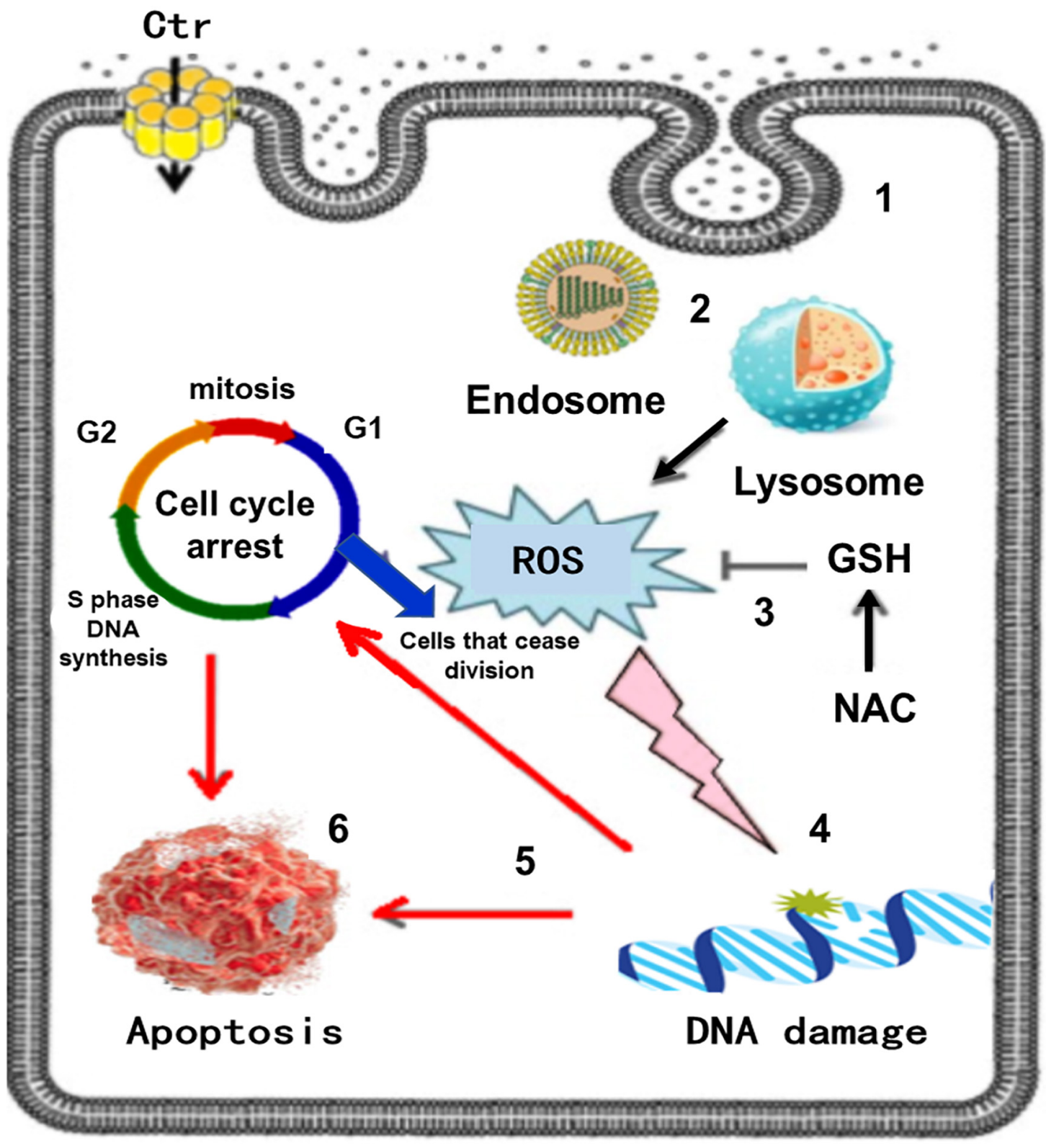

FIGURE 12 | In vitro toxicity model of CuO NPs, the sequence of events in Poly toxicity. (1) CuO NPs are taken up via endocytosis, (2) Endocytotic vesicles are converted to lysosomes via autophagy, (3) ROS generation, other molecules can be oxidized mitigated by the antioxidant GSH and its precursor NAC, (4) ROS attacks DNA in the nucleus, (5) DNA damage activates signaling systems that induce cell cycle arrest, (6) Cell death by apoptosis. Reproduced from Thit et al. (2015) with permission.

liver, kidney, brain, blood, lung, heart, urine, and feces (Lee et al., 2016). The CuO NPs exposed rats for up to 26 days showed some signs of increased Alanine Aminotransferase (ALT) levels as a liver damage index, also in $512 \mathrm{mg} / \mathrm{kg}$ dosage, no variations of histopathology were detected in liver, bone marrow, and stomach. The released $\mathrm{Cu}$ ions interfered with the immune system by lymphoid cell depletion in thymus and spleen organs, it should be said that the dissolution and biodistribution of NPs have a potential to act as a key factor in the toxic behavior of $\mathrm{CuO}$ treated samples (De Jong et al., 2019). Other studies in relation to the toxicity issues of metal and metal oxide NPs are listed in Table 3.

\section{Toxicity Prevention in Metallic and Metal Oxide NPs}

The size, morphology, concentration, aggregation mode, charge, surface properties all have an impact on toxicity and must be considered in order to prevent the harmful effects of NPs. It 
TABLE 3 | In vitro and in vivo nanotoxicology studies of metal and metal oxide nanoparticles.

\begin{tabular}{|c|c|c|c|c|c|}
\hline Material & Condition & Properties & $\begin{array}{l}\text { Cell line or animal } \\
\text { model }\end{array}$ & Conclusion & References \\
\hline \multirow[t]{4}{*}{ Ag } & In vitro & $20-30 \mathrm{~nm}$ & Caco-2, SW480 & $\begin{array}{l}\text { No significant ROS generation, increased inflammation, increased cell death and } \\
\text { cell stress. }\end{array}$ & $\begin{array}{l}\text { Abbott Chalew and } \\
\text { Schwab, } 2013\end{array}$ \\
\hline & & Two nano-sized and two microsized & $\begin{array}{l}\text { Human red blood } \\
\text { cells }\end{array}$ & $\begin{array}{l}\text { NPs were more hemolytic than micron-sized particles at equivalent mass } \\
\text { concentrations }>220 \mu \mathrm{g} / \mathrm{ml} \text { and at surface area concentrations }>10 \mathrm{~cm}(2) / \mathrm{ml} \text {, } \\
\text { NPs released more Ag ions than microsized particles. }\end{array}$ & Choi et al., 2011 \\
\hline & In vivo & $\begin{array}{l}\text { Silver-coated wound dressing Acticoat } \\
\text { (1 week) }\end{array}$ & $\begin{array}{l}\text { Human burns } \\
\text { patient }\end{array}$ & $\begin{array}{l}\text { Hepatotoxicity and argyria-like symptoms, Ag increase in plasma, urine and liver } \\
\text { enzymes. }\end{array}$ & Trop et al., 2006 \\
\hline & & $\begin{array}{l}\text { 30, } 300 \text { or } 1000 \mathrm{mg} / \mathrm{kg} / \text { day for } 28 \\
\text { days (60 } \mathrm{nm} \text { in size) per oral }\end{array}$ & $\begin{array}{l}\text { Sprague- } \\
\text { Dawley rats }\end{array}$ & $\begin{array}{l}\text { Higher than } 300 \text { mg of NPs may result in slight liver damage, do not induce genetic } \\
\text { toxicity, a gender-related difference in the accumulation of silver was noted in the } \\
\text { kidneys, with a twofold increase in the female kidneys. }\end{array}$ & Kim et al., 2008 \\
\hline Al & In vitro & $<500 \mathrm{~nm}$ & $\begin{array}{l}\text { A549, } \\
\text { THP-1 }\end{array}$ & Low toxicity in MTT assay. & Lanone et al., 2009 \\
\hline $\mathrm{Ni}$ & In vitro & $<500 \mathrm{~nm}$ & A549, THP-1 & Low to moderate toxicity in MTT assay. & Lanone et al., 2009 \\
\hline Co & In vitro & $<500 \mathrm{~nm}$ & A549, THP-1 & $\begin{array}{l}\text { Co NPs induced toxicity only when incorporated as a Nickel-Cobalt-Manganese } \\
\text { mixed variant. }\end{array}$ & Lanone et al., 2009 \\
\hline \multirow[t]{4}{*}{$\mathrm{Au}$} & In vitro & $\begin{array}{l}\text { Nanorods with 4:1 length-to-diameter } \\
\text { ratio }\end{array}$ & HT29 & Cytotoxicity caused by free CTAB, overcoating with polymer is useful. & Alkilany et al., 2009 \\
\hline & In vivo & $\begin{array}{l}8 \mathrm{mg} / \mathrm{kg} / \text { week (3-100 } \mathrm{nm} \text { in size) } \\
\text { (4 weeks) intraperitoneal }\end{array}$ & BALB/C mice & $\begin{array}{l}\text { NPs ranging from } 8 \text { to } 37 \mathrm{~nm} \text { induced severe sickness, fatigue, loss of appetite, } \\
\text { change of fur color, and weight loss, from day } 14 \text { they exhibited a camel-like back } \\
\text { and crooked spine. Pathological studies showed an increase of Kupffer cells in the } \\
\text { liver, loss of structural integrity in the lungs, and diffusion of white pulp in the spleen. }\end{array}$ & Chen et al., 2009 \\
\hline & & $\begin{array}{l}0.17,0.85 \text {, and } 4.26 \mathrm{mg} / \mathrm{kg} \text { body } \\
\text { weight }(13 \mathrm{~nm} \text { in size), }(30 \mathrm{~min} \\
\text { after injection for } 7 \text { days) } \\
\text { Intravenous, coated with PEG }\end{array}$ & BALB/C mice & $\begin{array}{l}\text { Acute inflammation and apoptosis in the liver, NPs accumulate in the liver and } \\
\text { spleen for up to } 7 \text { days with long blood circulation times, NPs presence in } \\
\text { cytoplasmic vesicles and lysosomes of liver Kupffer cells and spleen macrophages. }\end{array}$ & Cho W.S. et al., 2009 \\
\hline & & $\begin{array}{l}(12.5 \mathrm{~nm} \text { in size) }(40,200, \text { or } \\
400 \mu \mathrm{g} / \mathrm{kg} / \text { day for } 8 \text { days), } \\
\text { intraperitoneal }\end{array}$ & C57/BL6 mice & $\begin{array}{l}\text { NPs internalized inside the cell via a mechanism involving pinocytosis, also NPs } \\
\text { internalization in lysosomal bodies arranged in perinuclear fashion, Au NPs were } \\
\text { non-cytotoxic, non-immunogenic, and biocompatible properties. }\end{array}$ & Shukla et al., 2005 \\
\hline \multirow[t]{5}{*}{$\mathrm{Ti}$ and $\mathrm{TiO}_{2}$} & In vitro & $10-300 \mathrm{~nm}$ & Caco-2 & $\begin{array}{l}\text { DNA damage dependency on sample processing conditions, cytotoxic in LDH and } \\
\text { WST-1 assay. }\end{array}$ & Gerloff et al., 2009 \\
\hline & & $21 \mathrm{~nm}$ & Caco-2, SW480 & $\begin{array}{l}\text { No significant ROS generation, increased inflammation, increased cell death and } \\
\text { cell stress. }\end{array}$ & $\begin{array}{l}\text { Abbott Chalew and } \\
\text { Schwab, } 2013\end{array}$ \\
\hline & & $21 \mathrm{~nm}$ & 16HBE, A549 & $\begin{array}{l}\text { No considerable effect on } 16-\mathrm{HBE} \text { or A549 cell viability, strong aggregation in } \\
\text { culture media. }\end{array}$ & Guadagnini et al., 2015 \\
\hline & & $<500 \mathrm{~nm}$ & A549, THP-1 & Moderate toxicity in MTT assay. & Lanone et al., 2009 \\
\hline & In vivo & $\begin{array}{l}\text { NPs containing sunscreen, mean } \\
\text { particle size of } 20 \mathrm{~nm}\end{array}$ & $\begin{array}{l}\text { Human } \\
\text { volunteers }\end{array}$ & $\begin{array}{l}\text { NPs penetrate deeper into human skin from an oily dispersion than from an } \\
\text { aqueous one. }\end{array}$ & $\begin{array}{l}\text { Bennat and } \\
\text { Müller-Goymann, } 2000\end{array}$ \\
\hline \multirow[t]{2}{*}{ Zno } & In vitro & $20 \mathrm{~nm}$ & Caco-2, SW480 & $\begin{array}{l}\text { Toxic but no significant ROS generation, increased inflammation, increased cell } \\
\text { death and cell stress. }\end{array}$ & $\begin{array}{l}\text { Abbott Chalew and } \\
\text { Schwab, } 2013\end{array}$ \\
\hline & & $10-20 \mathrm{~nm}$ & Caco-2 & DNA damage, cytotoxic in LDH and WST-1 assay. & Gerloff et al., 2009 \\
\hline
\end{tabular}




\begin{tabular}{|c|c|c|c|c|c|}
\hline Material & Condition & Properties & $\begin{array}{l}\text { Cell line or animal } \\
\text { model }\end{array}$ & Conclusions & References \\
\hline & & $<500 \mathrm{~nm}$ & A549, THP-1 & High toxicity in MTT assay. & Lanone et al., 2009 \\
\hline & & 288.2 and 265.7 & $\begin{array}{l}\text { Alveolar type II } \\
\text { epithelial cells } \tilde{N} 10\end{array}$ & $\begin{array}{l}\text { Oxidative stress generation induced by } \mathrm{Zn} \text { ions, Decrease in cell viability after } 6 \text { and } \\
24 \mathrm{~h} \text { of incubation. }\end{array}$ & Xie et al., 2012 \\
\hline & In vivo & $\begin{array}{l}\text { Coated and uncoated NPs with } \\
74.0 \mathrm{~nm} \text { and } 65.0 \mathrm{~nm} \text { size }\end{array}$ & Human volunteers & $\begin{array}{l}\text { NPs did not enter or cause cellular toxicity in the viable epidermis, Zinc ion } \\
\text { concentrations slightly increased, repeated application of ZnO NPs to the skin, as } \\
\text { used in sunscreen products was determined as safe. }\end{array}$ & Mohammed et al., 2019 \\
\hline MgO & In vitro & $8 \mathrm{~nm}$ & Caco-2 & No cytotoxicity in LDH and WST-1 assay. & Gerloff et al., 2009 \\
\hline \multirow[t]{6}{*}{$\mathrm{SiO}$ and $\mathrm{SiO}_{2}$} & In vitro & $14 \mathrm{~nm}$ & Caco-2 & Glutathione depletion, DNA damage, cytotoxic in LDH and WST-1 assay. & Gerloff et al., 2009 \\
\hline & & $\begin{array}{l}25 \text { and } 50 \mathrm{~nm} \text {, modified and not } \\
\text { modified with sodium oleate }\end{array}$ & 16HBE, A549 & $\begin{array}{l}\text { Dose, time and size dependent effects, } 25 \mathrm{~nm} \text { NPs are more toxic than } 50 \mathrm{~nm} \text { ones } \\
\text { at lower concentrations, ROS generation ROS at toxic concentrations. }\end{array}$ & Guadagnini et al., 2015 \\
\hline & & $100 \mathrm{~nm}$ & HeLa, ЗT3 & $\begin{array}{l}\text { Cell viability and survival decreased only about } 20 \% \text { at high concentration of } \\
100 \mu \mathrm{g} / \mathrm{mL} \text {, no significant toxic effects. }\end{array}$ & Xia et al., 2013 \\
\hline & In vivo & $\begin{array}{l}20 \mathrm{mg} / \text { animal ( } 1 \text { or } 2 \text { months), } \\
\text { intratracheal instillation }\end{array}$ & Wistar rats & $\begin{array}{l}\text { Changes in pathology and fibrotic grade, the lung/body coefficient and } \\
\text { hydroxyproline content of } \mathrm{SiO}_{2} \mathrm{NPs} \text { were lower than microsized } \mathrm{SiO}_{2} \text {. }\end{array}$ & Chen et al., 2004 \\
\hline & & $\begin{array}{l}50 \mathrm{mg} / \mathrm{kg}(50,100 \text { or } 200 \mathrm{~nm} \text { in size), } \\
\text { (12, } 24,48 \text { and } 72 \mathrm{~h}, 7 \text { days) } \\
\text { intravenous }\end{array}$ & $\begin{array}{l}\mathrm{BALB} / \mathrm{C} \\
\text { mice }\end{array}$ & $\begin{array}{l}\text { NPs trapped by macrophages in the spleen and liver and remained there until } \\
4 \text { weeks after the single injection, Macrophage mediated frustrated phagocytosis of } \\
\text { larger NPs resulted in release of pro-inflammatory cytokines and cell infiltrates within } \\
\text { hepatic parenchyma. }\end{array}$ & Cho M. et al., 2009 \\
\hline & & $\begin{array}{l}2 \mathrm{mg} / \mathrm{kg}(20-25 \mathrm{~nm} \text { in size) }(24 \mathrm{~h}) \\
\text { intravenous }\end{array}$ & Nude mice & $\begin{array}{l}\text { Higher accumulation of NPs in liver, spleen, and stomach than in kidney, heart, and } \\
\text { lungs, hepatobiliary excretion of NPs after } 15 \text { days. }\end{array}$ & Kumar et al., 2010 \\
\hline \multirow[t]{5}{*}{$\mathrm{Cu}, \mathrm{CuO}$ and $\mathrm{CuS}$} & In vitro & 50 and $100 \mathrm{~nm}$, surface charge & Caco-2 & $\begin{array}{l}\text { Positively charged NPs have higher toxicity and cell uptake, NPs transfer is a } \\
\text { dynamin-dependent process. }\end{array}$ & Bannunah et al., 2014 \\
\hline & & $50 \mathrm{~nm}$ & $\begin{array}{l}\text { A549, } \\
\text { SAEC }\end{array}$ & $\begin{array}{l}\text { Cell cycle arrest by Cu ions, highly toxic, inhibition of cell proliferation genes, } \\
\text { apoptosis. }\end{array}$ & Hanagata et al., 2011 \\
\hline & & $<500 \mathrm{~nm}$ & $\begin{array}{l}\text { A549, } \\
\text { THP-1 }\end{array}$ & High toxicity in MTT assay. & Lanone et al., 2009 \\
\hline & & $\begin{array}{l}\text { Length of } 59.4 \mathrm{~nm} \text { and thickness of } \\
23.8 \mathrm{~nm}\end{array}$ & $\begin{array}{l}\text { HUVECs, RAW } \\
264.7, \mathrm{~KB}, \mathrm{HeLa}\end{array}$ & $\begin{array}{l}\text { Cell viability reduction in HUVECs at higher than } 100 \mu \mathrm{g} / \mathrm{mL} \text { dosages, toxicity to } \\
\text { HUVEC and RAW } 264.7 \text { cells, NPs uptake in RAW } 264.7 \text { cells, no considerable } \\
\text { change in cytoskeleton components. }\end{array}$ & Feng et al., 2015 \\
\hline & In vivo & $\begin{array}{l}\text { Micro-Cu (1 } \mu \mathrm{m}) \text {, and nano-Cu } \\
(80-100 \mathrm{~nm}) \text {, }\end{array}$ & $\begin{array}{l}\text { Sprague-Dawley } \\
\text { rats }\end{array}$ & $\begin{array}{l}\text { Cu NPs changed the immune function of the spleen, Alteration in the number of } \\
\text { blood cells in rats and lymphocyte subpopulation in the spleen, antibody production } \\
\text { and obvious histopathology changes. }\end{array}$ & Zhou et al., 2019 \\
\hline \multirow[t]{3}{*}{$\mathrm{FeO}$ and $\mathrm{Fe}_{3} \mathrm{O}_{4}$} & In vitro & $\begin{array}{l}10 \mathrm{~nm} \text {, without and with } \\
\text { polyethylenoxide (PEO) coating }\end{array}$ & $\begin{array}{l}\text { PC3, C4-2, } \\
\text { HUVECS }\end{array}$ & $\begin{array}{l}\text { Viability reduction, coated NPs uptake by cells, the surface-modified NPs are more } \\
\text { toxic than NPs without shells. }\end{array}$ & Häfeli et al., 2009 \\
\hline & & $\begin{array}{l}8 \mathrm{~nm} \text {, modified and not } \\
\text { modified with sodium oleate }\end{array}$ & 16HBE, A549 & $\begin{array}{l}\text { Sodium oleate coating led to an increase in cytotoxicity, strong aggregation in } \\
\text { culture media, toxic and inducing cytotoxicity in a dose, time and coating } \\
\text { dependent manner. }\end{array}$ & Guadagnini et al., 2015 \\
\hline & In vivo & $\begin{array}{l}\text { Ferrite and manganese ferrite oxide } \\
\text { with sizes between } 3 \text { and } 20 \mathrm{~nm}\end{array}$ & $\begin{array}{l}\text { Zebrafish embryos } \\
\text { and mice }\end{array}$ & $\begin{array}{l}\text { In manganese-based NPs concentrations above } 100 \mu \mathrm{g} / \mathrm{mL} \text { showed a low survival } \\
\text { rate }(<50 \%) \text {, absence of toxicity in mice }\end{array}$ & Caro et al., 2019 \\
\hline $\mathrm{CeO}_{2}$ & In vitro & $\begin{array}{l}15,25,30 \text {, and } \\
45 \mathrm{~nm}\end{array}$ & $\begin{array}{l}\text { BEAS- } \\
2 B\end{array}$ & $\begin{array}{l}\text { ROS generation led to cell death, NPs absorption by cells and localized in the } \\
\text { perinuclear space }\end{array}$ & Park et al., 2008 \\
\hline
\end{tabular}

A549, THP-1 pithelial cells $\tilde{N} 10$

Dose, time and size dependent effects, $25 \mathrm{~nm}$ NPs are more toxic than $50 \mathrm{~nm}$ ones at lower concentrations, ROS generation ROS at toxic concentrations.

Changes in pathology and fibrotic grade, the lung/body coefficient and hydroxyproline content of $\mathrm{SiO}_{2} \mathrm{NPs}$ were lower than microsized $\mathrm{SiO}_{2}$.

4 weeks after the single iniection, Macrophage medlated frustrated phagocytosis of larger NPs resulted in release of pro-inflammatory cytokines and cell infiltrates within hepatic parenchyma.

Cell viability reduction in HUVECs at higher than $100 \mu \mathrm{g} / \mathrm{mL}$ dosages, toxicity to HUVEC and RAW 264.7 cells, NPs uptake in RAW 264.7 cells, no considerable and obvious histopathology changes.

toxic than NPs without shells.

endent manner.

ish embryos perinuclear space 
was known that toxicity of metallic and metal oxide NPs is directly related to its surface properties hence alterations in the surface of these NPs can be a good idea for mitigating their possible harmful effects. In this regard, various safe surface designs are the spotlights and can be listed as utilization of surface coatings (Osmond-McLeod et al., 2013), core-shell structures (Davidson et al., 2015), doping-based methods (Wang et al., 2012), geometric control (Ji et al., 2012), and surface passivation methods (Cai et al., 2017). Among these methods, the coating approaches seem to be simpler and more controllable and it is almost applicable to every metallic NPs. These methods can affect the surface reactivity and ion outlet in order to avoid any cytotoxic occurrence. One of the coating and surface passivation methods is sulfidation, for example, the existence of sulfide can avoid $\mathrm{AgNO}_{3}$ toxicity (Bowles et al., 2002). Also, Levard et al. (2013) reported that sulfidation of silver NPs can hinder Ag ion mobility and reduce its dissolution rate. Considering gastrointestinal digestion impact, Martirosyan et al. (2014) used food matrix component phenolic compounds (PCs) to prevent from the toxicology of Ag NPs. In this regard, two major factors involving in the toxicity of Ag NPs (the release of $\mathrm{Ag}^{+}$and ROS) were studied. Results showed that two PCs, quercetin and kaempferol, relatively defended the Caco-2 cells from Ag NPs induced toxicity and these PCs protected the epithelial barrier integrity which disrupted by NPs. Future investigations seem to be necessary to find more sophisticated methods in order to precise and complete toxicity prevention.

\section{CONCLUSION}

Nanotechnology as one of the exciting and modern branches of science found a lot of applications in various technologies from the food and cosmetic industry to medicine and agriculture, hence humanity is in direct contact with these nanoparticles (NPs). Although, the nanosized materials have many benefits compared to coarse sizes they can also have unfavorable effects since they have the potential to pass the natural barriers of live cells and tissues and cause toxic and inflammatory issues. Because of these problems, a new branch of science entitled nanotoxicology has emerged with the aim to elucidate the possible effects of NPs and the related parameters affecting the cytotoxicity of nanomaterials. Metal and metal oxide materials are among the most used NPs so this review paper dedicated to analyze the key factors influencing the toxicity of these NPs and review the in vitro and in vivo studies to find out the possible hazards of NPs and found a detailed guideline to control and decrease the adverse effects of metal and metal oxide NPs. In order to attain this goal, firstly the toxicity mechanisms including reactive oxygen species (ROS) generation, the effect of NPs on cell membranes, cytoskeleton components, DNA, mitochondria, and lysosomes was discussed. Secondly, because of the obvious effects of physical and chemical characteristics on toxicity, they were carefully reviewed. It was found that the size of NPs has a significant effect since its nano-sized range by increasing the specific surface area led to more cellular interactions and toxicity. The other key factors affecting the cytotoxicity of NPs are shape and dimensionality, chemical composition and NPs concentration or dosage, crystalline structures, solubility, hydrophilicity, surface charge, and agglomeration condition. In this regard, it was believed that it is critical to control the physicochemical properties of NPs in order to achieve more safe and reliable NPs since even natural non-toxic and even antibacterial materials such as $\mathrm{Ag}, \mathrm{Cu}, \mathrm{Ti}$, and $\mathrm{Zn}$ can induce toxicity in some ranges of size, dosage and surface charges. Overall, it seems that violating the cell passage system for example by decreasing the size of NPs to smaller than cellular subunits, organelles, and cells and letting them permeate and enter into the biological structures should be strictly prevented. Thirdly, some highlight findings of in vitro and in vivo studies about the toxicity of metal and metal oxide NPs were discussed to determine key factors. In the end, it is hoped that increasing the awareness and information about this subject opens a new horizon to understand more about the nanotoxicology and design the modern materials and procedures with the safe thresholds. These modern NPs should be designed meticulously by taking into account all the intriguing and complex aspects that arise from nanometric size ranges and also the other affecting factors.

The emerging trends and prospects in metallic NPs' toxicity studies are quite broad including modern NPs designs with optimal properties, enhancing their favorable effects and minimizing the potential toxicity, detection of toxicity transmitting species and targets by considering their life cycle, incorporation of various coating and surface treatments to decrease the harmful results while maintaining the favorable properties. Many aspects of these issues are still unsolved and need further studies in the future to overcome the toxicity limitations of metallic NPs and other present to-date barriers. In this regard, methods based on the simultaneous use of NPs with antitoxic strategies seem to be more promising. Also, in future studies, more attention should be paid to possible effects of biological fluids and surrounding tissues, biokinetics, involved mechanisms, and other chemical and biological factors. Moreover, there is a demand for more sophisticated and validated in vitro models that are prognostic of in vivo experiments outcomes. Finally, the resultant guidelines should have a potency to underlie the exact NPs' interactions with biological systems in order to support a complete correct risk assessment. Hence, various scientific disciplines including chemistry, physics, medicine, and biology should be involved and interact together to shade light on all the complex cellularmolecular events.

\section{AUTHOR CONTRIBUTIONS}

SA wrote the main part of the manuscript. QW and JuY greatly contributed to the titanium and copper parts. ME made major contributions particularly in choosing the figures. SA, JiY, ME, and JL made significant contribution to the revision stage. YT and SA prepared and formulated the references. All the authors contributed to the article and approved the submitted version. 


\section{FUNDING}

The authors would like to acknowledge the financial supports provided by National Natural Science Foundation of China under Grant Nos. 51674167 and 81828007, High-level Innovation team

\section{REFERENCES}

Abbasalipourkabir, R., Moradi, H., Zarei, S., Asadi, S., Salehzadeh, A., Ghafourikhosroshahi, A., et al. (2015). Toxicity of zinc oxide nanoparticles on adult male Wistar rats. Food Chem. Toxicol. 84, 154-160. doi: 10.1016/j.fct.2015. 08.019

Abbott Chalew, T. E., and Schwab, K. J. (2013). Toxicity of commercially available engineered nanoparticles to Caco-2 and SW480 human intestinal epithelial cells. Cell Biol. Toxicol. 29, 101-116. doi: 10.1007/s10565-013-9241-6

Abdelgied, M., El-Gazzar, A. M., Alexander, D. B., Alexander, W. T., Numano, T., Iigou, M., et al. (2019). Pulmonary and pleural toxicity of potassium octatitanate fibers, rutile titanium dioxide nanoparticles, and MWCNT-7 in male Fischer 344 rats. Arch. Toxicol. 93, 909-920. doi: 10.1007/s00204-019-02410-z

Adeyemi, J. A., Machado, A. R. T., Ogunjimi, A. T., Alberici, L. C., Antunes, L. M. G., and Barbosa, F. (2020). Cytotoxicity, mutagenicity, oxidative stress and mitochondrial impairment in human hepatoma (HepG2) cells exposed to copper oxide, copper-iron oxide and carbon nanoparticles. Ecotoxicol. Environ. Saf. 189:109982. doi: 10.1016/j.ecoenv.2019.109982

Akter, M., Sikder, M. T., Rahman, M. M., Ullah, A. K. M. A., Hossain, K. F. B., Banik, S., et al. (2018). A systematic review on silver nanoparticles-induced cytotoxicity: physicochemical properties and perspectives. J. Adv. Res. 9, 1-16. doi: 10.1016/j.jare.2017.10.008

Alkilany, A. M., Nagaria, P. K., Hexel, C. R., Shaw, T. J., Murphy, C. J., and Wyatt, M. D. (2009). Cellular uptake and cytotoxicity of gold nanorods: molecular origin of cytotoxicity and surface effects. Small 5, 701-708. doi: 10.1002/smll. 200801546

Ansarian, I., Shaeri, M. H., Ebrahimi, M., Minárik, P., and Bartha, K. (2019). Microstructure evolution and mechanical behaviour of severely deformed pure titanium through multi directional forging. J. Alloys Compd. 776, 83-95. doi: 10.1016/j.jallcom.2018.10.196

Asati, A., Santra, S., Kaittanis, C., and Perez, J. M. (2010). Surface-chargedependent cell localization and cytotoxicity of cerium oxide nanoparticles. ACS Nano 4, 5321-5331. doi: 10.1021/nn100816s

ASTM (2012). ASTM E2456-06, Standard Terminology Relating to Nanotechnology. West Conshohocken, PA: ASTM International.

Attarilar, S., Djavanroodi, F., Irfan, O. M., Al-Mufadi, F. A., Ebrahimi, M., and Wang, Q. D. (2020). Strain uniformity footprint on mechanical performance and erosion-corrosion behavior of equal channel angular pressed pure titanium. Results Phys. 17:103141. doi: 10.1016/j.rinp.2020.103141

Attarilar, S., Salehi, M. T., Al-Fadhalah, K. J., Djavanroodi, F., and Mozafari, M. (2019). Functionally graded titanium implants: characteristic enhancement induced by combined severe plastic deformation. PLoS One 14:e0221491. doi: 10.1371/journal.pone.0221491

Bannunah, A. M., Vllasaliu, D., Lord, J., and Stolnik, S. (2014). Mechanisms of nanoparticle internalization and transport across an intestinal epithelial cell model: effect of size and surface charge. Mol. Pharm. 11, 4363-4373. doi: 10. $1021 / \mathrm{mp} 500439 \mathrm{c}$

Ben Younes, N. R., Amara, S., Mrad, I., Ben-Slama, I., Jeljeli, M., and Omri, K. (2015). Subacute toxicity of titanium dioxide ( $\mathrm{TiO} 2$ ) nanoparticles in male rats: emotional behavior and pathophysiological examination. Environ. Sci. Pollut. Res. 22, 8728-8737. doi: 10.1007/s11356-014-4002-5

Bennat, C., and Müller-Goymann, C. C. (2000). Skin penetration and stabilization of formulations containing microfine titanium dioxide as physical UV filter. Int. J. Cosmet. Sci. 22, 271-283. doi: 10.1046/j.1467-2494.2000.00009.x

Berce, C., Lucan, C., Petrushev, B., Boca, S., Miclean, M., Sarpataki, O., et al. (2016). In vivo assessment of bone marrow toxicity by gold nanoparticle-based bioconjugates in CrL:CD1(ICR) mice. Int. J. Nanomedicine 11, 4261-4273. doi: $10.2147 /$ IJN.S108711

Bowles, K. C., Bianchini, A., Brauner, C. J., Kramer, J. R., and Wood, C. M. (2002). Evaluation of the effect of reactive sulfide on the acute toxicity of silver (I) to and Outstanding Scholars Program of Colleges and University in Guangxi: Innovative team of basic and Clinical Comprehensive Research on Bone and Joint Degenerative Diseases, and Open Foundation of Guangxi Key Laboratory of Processing for Nonferrous Metals and Featured Materials (2019GXYSOF01).

Daphnia magna. Part 1: description of the chemical system. Environ. Toxicol. Chem. 21, 1286-1293.

Bressan, E., Ferroni, L., Gardin, C., Rigo, C., Stocchero, M., Vindigni, V., et al. (2013). Silver nanoparticles and mitochondrial interaction. Int. J. Dentistry 2013, 1-8.

Brooker, R. J. (2018). Genetics: Analysis \& Principles, 6th Edn. New York, NY: McGraw-Hill Science.

Buzea, C., Pacheco, I. I., and Robbie, K. (2007). Nanomaterials and nanoparticles: sources and toxicity. Biointerphases 2, MR17-MR71. doi: 10.1116/1.2815690

Cai, X., Lee, A., Ji, Z., Huang, C., Chang, C. H., Wang, X., et al. (2017). Reduction of pulmonary toxicity of metal oxide nanoparticles by phosphonate-based surface passivation. Part Fibre Toxicol. 14, 1-11. doi: 10.1186/s12989-017-0193-5

Caro, C., Egea-Benavente, D., Polvillo, R., Royo, J. L., Pernia Leal, M., and García-Martín, M. L. (2019). Comprehensive toxicity assessment of PEGylated magnetic nanoparticles for in vivo applications. Colloids Surfaces B Biointerfaces 177, 253-259. doi: 10.1016/j.colsurfb.2019.01.051

Champion, J. A., and Mitragotri, S. (2006). Role of target geometry in phagocytosis. Proc. Natl. Acad. Sci. U.S.A. 103, 4930-4934. doi: 10.1073/pnas.0600997103

Chen, H. (2018). Metal based nanoparticles in agricultural system: behavior, transport, and interaction with plants. Chem. Speciat. Bioavailab. 30, 123-134. doi: 10.1080/09542299.2018.1520050

Chen, Q., Wang, N., Zhu, M., Lu, J., and Zhong, H. (2018). Redox Biology TiO 2 nanoparticles cause mitochondrial dysfunction, activate in $\mathrm{fl}$ ammatory responses, and attenuate phagocytosis in macrophages: a proteomic and metabolomic insight. Redox Biol. 15, 266-276. doi: 10.1016/j.redox.2017.12.011

Chen, Y., Chen, J., Dong, J., and Jin, Y. (2004). Comparing study of the effect of nanosized silicon dioxide and microsized silicon dioxide on fibrogenesis in rats. Toxicol. Ind. Health 20, 21-27. doi: 10.1191/0748233704th190oa

Chen, Y.-S., Hung, Y.-C., Liau, I., and Huang, G. S. (2009). Assessment of the in vivo toxicity of gold nanoparticles. Nanoscale Res. Lett. 4, 858-864. doi: 10.1007/s11671-009-9334-6

Cho, M., Cho, W.-S., Choi, M., Kim, S. J., Han, B. S., Kim, S. H., et al. (2009). The impact of size on tissue distribution and elimination by single intravenous injection of silica nanoparticles. Toxicol. Lett. 189, 177-183. doi: 10.1016/j. toxlet.2009.04.017

Cho, W.-S., Cho, M., Jeong, J., Choi, M., Cho, H.-Y., and Han, B. S. (2009). Acute toxicity and pharmacokinetics of $13 \mathrm{~nm}$-sized PEG-coated gold nanoparticles. Toxicol. Appl. Pharmacol. 236, 16-24. doi: 10.1016/j.taap.2008.12.023

Choi, J., Reipa, V., Hitchins, V. M., Goering, P. L., and Malinauskas, R. A. (2011). Physicochemical characterization and in vitro hemolysis evaluation of silver nanoparticles. Toxicol. Sci. 123, 133-143. doi: 10.1093/toxsci/kfr149

Coradeghini, R., Gioria, S., García, C. P., Nativo, P., Franchini, F., Gilliland, D., et al. (2013). Size-dependent toxicity and cell interaction mechanisms of gold nanoparticles on mouse fibroblasts. Toxicol. Lett. 217, 205-216. doi: 10.1016/j. toxlet.2012.11.022

Davidson, D. C., Derk, R., He, X., Stueckle, T. A., Cohen, J., Pirela, S. V., et al. (2015). Direct stimulation of human fibroblasts by $\mathrm{nCeO} 2$ in vitro is attenuated with an amorphous silica coating. Part. Fibre Toxicol. 13:23. doi: 10.1186/ s12989-016-0134-8

Dayem, A. A., Hossain, M. K., Bin Lee, S., Kim, K., Saha, S. K., Yang, G., et al. (2017). The role of reactive oxygen species (ROS) in the biological activities of metallic nanoparticles. Int. J. Mol. Sci. 18, 1-21. doi: 10.3390/ijms18010120

De Angelis, I., Barone, F., Zijno, A., Bizzarri, L., Russo, M. T., Pozzi, R., et al. (2013). Comparative study of $\mathrm{ZnO}$ and $\mathrm{TiO} 2$ nanoparticles: physicochemical characterisation and toxicological effects on human colon carcinoma cells. Nanotoxicology 7, 1361-1372. doi: 10.3109/17435390.2012.741724

De Jong, W. H., De Rijk, E., Bonetto, A., Wohlleben, W., Stone, V., Brunelli, A., et al. (2019). Toxicity of copper oxide and basic copper carbonate nanoparticles after short-term oral exposure in rats. Nanotoxicology 13, 50-72. doi: 10.1080/ 17435390.2018 .1530390 
De Jong, W. H., Hagens, W. I., Krystek, P., Burger, M. C., Sips, A. J. A. M., and Geertsma, R. E. (2008). Particle size-dependent organ distribution of gold nanoparticles after intravenous administration. Biomaterials 29, 1912-1919. doi: 10.1016/j.biomaterials.2007.12.037

De Matteis, V., Cascione, M., Brunetti, V., Toma, C. C., and Rinaldi, R. (2016). Toxicity assessment of anatase and rutile titanium dioxide nanoparticles: the role of degradation in different $\mathrm{pH}$ conditions and light exposure. Toxicol. Vitr. 37, 201-210. doi: 10.1016/j.tiv.2016.09.010

Devasagayam, T. P. A., Tilak, J. C., Boloor, K. K., Sane, K., Ghaskadbi, S., and Lele, R. (2004). Free radicals and antioxidants in human health: current status and future prospects. J. Assoc. Physicians India 52, 794-804.

Deyhle, H., Schulz, G., and Bert, M. (2012). Encyclopedia of Nanotechnology. Berlin: Springer Netherlands. Dordrecht.

Dhall, A., and Self, W. (2018). Cerium oxide nanoparticles: a brief review of their synthesis methods and biomedical applications. Antioxidants 7, 1-13. doi: 10.3390/antiox7080097

Ding, Z., Zhang, C., Xie, L., Zhang, L.-C., Wang, L., and Lu, W. (2016). Effects of friction stir processing on the phase transformation and microstructure of TiO2-compounded Ti-6Al-4V alloy. Metall. Mater. Trans. A 47, 5675-5679. doi: 10.1007/s11661-016-3809-8

Dröge, W. (2002). Free radicals in the physiological control of cell function. Physiol. Rev. 82, 47-95. doi: 10.1152/physrev.00018.2001

El Badawy, A. M., Silva, R. G., Morris, B., Scheckel, K. G., Suidan, M. T., and Tolaymat, T. M. (2011). Surface charge-dependent toxicity of silver nanoparticles. Environ. Sci. Technol. 45, 283-287. doi: 10.1021/es1034188

El-Trass, A., ElShamy, H., El-Mehasseb, I., and El-Kemary, M. (2012). CuO nanoparticles: synthesis, characterization, optical properties and interaction with amino acids. Appl. Surf. Sci. 258, 2997-3001. doi: 10.1016/j.apsusc.2011. 11.025

Fabian, E., Landsiedel, R., Ma-Hock, L., Wiench, K., Wohlleben, W., and van Ravenzwaay, B. (2008). Tissue distribution and toxicity of intravenously administered titanium dioxide nanoparticles in rats. Arch. Toxicol. 82, 151-157. doi: 10.1007/s00204-007-0253-y

Fadeel, B., and Garcia-Bennett, A. E. (2010). Better safe than sorry: understanding the toxicological properties of inorganic nanoparticles manufactured for biomedical applications. Adv. Drug Deliv. Rev. 62, 362-374. doi: 10.1016/j.addr. 2009.11.008

Fahmy, H. M., Ebrahim, N. M., and Gaber, M. H. (2020). In-vitro evaluation of copper/copper oxide nanoparticles cytotoxicity and genotoxicity in normal and cancer lung cell lines. J. Trace Elem. Med. Biol. 60:126481. doi: 10.1016/j.jtemb. 2020.126481

Feng, W., Nie, W., Cheng, Y., Zhou, X., Chen, L., Qiu, K., et al. (2015). In vitro and in vivo toxicity studies of copper sulfide nanoplates for potential photothermal applications, Nanomedicine Nanotechnology. Biol. Med. 11, 901-912. doi: 10. 1016/j.nano.2014.12.015

Flores-López, L. Z., Espinoza-Gómez, H., and Somanathan, R. (2019). Silver nanoparticles: electron transfer, reactive oxygen species, oxidative stress, beneficial and toxicological effects. Mini review, J. Appl. Toxicol. 39, 16-26. doi: 10.1002/jat.3654

Fröhlich, E. (2013). Cellular targets and mechanisms in the cytotoxic action of non-biodegradable engineered nanoparticles. Curr. Drug Metab. 14, 976-988. doi: 10.2174/1389200211314090004

Gallud, A., Klöditz, K., Ytterberg, J., Östberg, N., Katayama, S., Skoog, T., et al. (2019). Cationic gold nanoparticles elicit mitochondrial dysfunction: a multiomics study. Sci. Reportsreports 9, 1-19. doi: 10.1038/s41598-019-40579-6

García-Hevia, L., Valiente, R., Martín-Rodríguez, R., Renero-Lecuna, C., González, J., Rodríguez-Fernández, L., et al. (2016). Nano-ZnO leads to tubulin macrotube assembly and actin bundling, triggering cytoskeletal catastrophe and cell necrosis. Nanoscale 8, 10963-10973. doi: 10.1039/C6NR00391E

Gea, M., Bonetta, S., Iannarelli, L., Giovannozzi, A. M., Maurino, V., Bonetta, S., et al. (2019). Shape-engineered titanium dioxide nanoparticles (TiO2-NPs): cytotoxicity and genotoxicity in bronchial epithelial cells. Food Chem. Toxicol. 127, 89-100. doi: 10.1016/j.fct.2019.02.043

Georgantzopoulou, A., Serchi, T., Cambier, S., Leclercq, C. C., Renaut, J., and Shao, J. (2016). Effects of silver nanoparticles and ions on a co-culture model for the gastrointestinal epithelium. Part. Fibre Toxicol. 13:9. doi: 10.1186/s12989-0160117-9
Gerloff, K., Albrecht, C., Boots, A. W., Frster, I., and Schins, R. P. F. (2009). Cytotoxicity and oxidative DNA damage by nanoparticles in human intestinal Caco-2 cells. Nanotoxicology 3, 355-364. doi: 10.3109/17435390903276933

Gode, C., Attarilar, S., Eghbali, B., and Ebrahimi, M. (2015). "Electrochemical behavior of equal channel angular pressed titanium for biomedical application," in AIP Conference Proceedings, College Park, ML: AIP.

Gogoi, S. K., Gopinath, P., Paul, A., Ramesh, A., Ghosh, S. S., and Chattopadhyay, A. (2006). Green fluorescent protein-expressing Escherichia coli as a model system for investigating the antimicrobial activities of silver nanoparticles. Langmuir 22, 9322-9328. doi: 10.1021/la060661v

Gopinath, P., Gogoi, S. K., Chattopadhyay, A., and Ghosh, S. S. (2008). Implications of silver nanoparticle induced cell apoptosis for in vitro gene therapy. Nanotechnology 19:075104. doi: 10.1088/0957-4484/19/7/075104

Gu, H., Ding, Z., Yang, Z., Yu, W., Zhang, W., and Lu, W. (2019) Microstructure evolution and electrochemical properties of TiO2/Ti-35Nb2Ta-3Zr micro/nano-composites fabricated by friction stir processing. Mater. Des. 169:107680. doi: 10.1016/j.matdes.2019.107680

Guadagnini, R., Moreau, K., Hussain, S., Marano, F., and Boland, S. (2015). Toxicity evaluation of engineered nanoparticles for medical applications using pulmonary epithelial cells. Nanotoxicology 9, 25-32. doi: 10.3109/17435390. 2013.855830

Guo, D., Zhang, J., Huang, Z., Jiang, S., and Gu, N. (2015). Colloidal silver nanoparticles improve anti-leukemic drug efficacy via amplification of oxidative stress. Colloids Surf. B Biointerfaces 126, 198-203. doi: 10.1016/j.colsurfb.2014. 12.023

Gurr, J. R., Wang, A. S. S., Chen, C. H., and Jan, K. Y. (2005). Ultrafine titanium dioxide particles in the absence of photoactivation can induce oxidative damage to human bronchial epithelial cells. Toxicology 213, 66-73. doi: 10.1016/j.tox. 2005.05.007

Haase, A., Rott, S., Mantion, A., Graf, P., Plendl, J., Thünemann, A. F., et al. (2012). Effects of silver nanoparticles on primary mixed neural cell cultures: uptake. Oxidative stress and acute calcium responses. Toxicol. Sci. 126, 457-468. doi: $10.1093 /$ toxsci/kfs003

Häfeli, U. O., Riffle, J. S., Harris-Shekhawat, L., Carmichael-Baranauskas, A., Mark, F., Dailey, J. P., et al. (2009). Cell uptake and in vitro toxicity of magnetic nanoparticles suitable for drug delivery. Mol. Pharm. 6, 1417-1428. doi: 10. $1021 / \mathrm{mp} 900083 \mathrm{~m}$

Halamoda Kenzaoui, B., Chapuis Bernasconi, C., Guney-Ayra, S., and JuilleratJeanneret, L. (2012). Induction of oxidative stress, lysosome activation and autophagy by nanoparticles in human brain-derived endothelial cells. Biochem. J. 441, 813-821. doi: 10.1042/BJ20111252

Hanagata, N., Zhuang, F., Connolly, S., Li, J., Ogawa, N., and Xu, M. (2011). Molecular responses of human lung epithelial cells to the toxicity of copper oxide nanoparticles inferred from whole genome expression analysis. ACS Nano 5, 9326-9338. doi: 10.1021/nn202966t

He, X. (2009). "Chapter 18 - integration of physical, chemical, mechanical, and biopharmaceutical properties in solid oral dosage form development," in Developing Solid Oral Dosage Forms, eds Y. Qiu, Y. Chen, G. Zhang, and G. Z. Liu (San Diego: Academic Press), 407-441.

Heinemann, D., Schomaker, M., Kalies, S., Schieck, M., Carlson, R., Escobar, H. M. et al. (2013). Gold nanoparticle mediated laser transfection for efficient sirna mediated gene knock down. PLoS One 8:e58604. doi: 10.1371/journal.pone. 0058604

Horie, M., Nishio, K., Fujita, K., Kato, H., Nakamura, A., and Kinugasa, S. (2009). Ultrafine $\mathrm{NiO}$ particles induce cytotoxicity in vitro by cellular uptake and subsequent $\mathrm{Ni}$ (II) release. Chem. Res. Toxicol. 22, 1415-1426. doi: 10.1021/ tx900171n

Hoseinpour, V., and Ghaemi, N. (2018). Green synthesis of manganese nanoparticles: applications and future perspective-A review. J. Photochem. Photobiol. B Biol. 189, 234-243. doi: 10.1016/j.jphotobiol.2018.10.022

Huang, Y. W., Cambre, M., and Lee, H. J. (2017). The toxicity of nanoparticles depends on multiple molecular and physicochemical mechanisms. Int. J. Mol. Sci. 18:2702. doi: 10.3390/ijms18122702

Huo, S., Jin, S., Ma, X., Xue, X., Yang, K., Kumar, A., et al. (2014). Ultrasmall gold nanoparticles as carriers for nucleus-based gene therapy due to size-dependent nuclear entry. ACS Nano 8, 5852-5862. doi: 10.1021/nn50 08572 
Ispanixtlahuatl-Meráz, O., Schins, R. P. F., and Chirino, Y. I. (2018). Cell type specific cytoskeleton disruption induced by engineered nanoparticles. Environ. Sci. Nano 5, 228-245. doi: 10.1039/c7en00704c

Ji, Z., Wang, X., Zhang, H., Lin, S., Meng, H., Sun, B., et al. (2012). Designed synthesis of $\mathrm{CeO} 2$ nanorods and nanowires for studying toxicological effects of high aspect ratio nanomaterials. ACS Nano 6, 5366-5380. doi: 10.1021/ nn3012114

Jia, Y. P., Ma, B. Y., Wei, X. W., and Qian, Z. Y. (2017). The in vitro and in vivo toxicity of gold nanoparticles. Chinese Chem. Lett. 28, 691-702. doi: 10.1016/j. cclet.2017.01.021

Jimeno-Romero, A., Oron, M., Cajaraville, M. P., Soto, M., and Marigómez, I. (2016). Nanoparticle size and combined toxicity of TiO2 and DSLS (surfactant) contribute to lysosomal responses in digestive cells of mussels exposed to $\mathrm{TiO} 2$ nanoparticles. Nanotoxicology 10, 1168-1176. doi: 10.1080/17435390. 2016.1196250

Jing, X., Park, J. H., Peters, T. M., and Thorne, P. S. (2015). Toxicity of copper oxide nanoparticles in lung epithelial cells exposed at the air-liquid interface compared with in vivo assessment. Toxicol. Vitr. 29, 502-511. doi: 10.1016/j.tiv. 2014.12.023

Kanchi, S., and Ahmed, S. (eds) (2018). Green Metal Nanoparticles. Hoboken, NJ: John Wiley \& Sons, Inc.

Karlsson, H. L., Cronholm, P., Gustafsson, J., and Möller, L. (2008). Copper oxide nanoparticles are highly toxic: a comparison between metal oxide nanoparticles and carbon nanotubes. Chem. Res. Toxicol. 21, 1726-1732. doi: 10.1021/ tx800064j

Katerji, M., Filippova, M., and Duerksen-Hughes, P. (2019). Approaches and methods to measure oxidative stress in clinical samples: research applications in the cancer field. Oxid. Med. Cell. Longev. 2019, 1-29. doi: 10.1155/2019/ 1279250

Kehrer, J. P., and Klotz, L.-O. (2015). Free radicals and related reactive species as mediators of tissue injury and disease: implications for Health. Crit. Rev. Toxicol. 45, 765-798. doi: 10.3109/10408444.2015.1074159

Khan, S. A. (2020). Metal Nanoparticles Toxicity: Role of Physicochemical Aspects. Amsterdam: Elsevier Inc.

Kim, C.-S., Nguyen, H.-D., Ignacio, R. M., Kim, J.-H., Cho, H.-C., and Maeng, E. H. (2014). Immunotoxicity of zinc oxide nanoparticles with different size and electrostatic charge. Int. J. Nanomedicine 9(Suppl. 2), 195-205. doi: 10.2147/IJN. S57935

Kim, Y. S., Kim, J. S., Cho, H. S., Rha, D. S., Kim, J. M., Park, J. D., et al. (2008). Twenty-eight-day oral toxicity, genotoxicity, and gender-related tissue distribution of silver nanoparticles in sprague-dawley rats. Inhal. Toxicol. 20, 575-583. doi: 10.1080/08958370701874663

Klębowski, B., Depciuch, J., Parlińska-Wojtan, M., and Baran, J. (2018). Applications of noble metal-based nanoparticles in medicine. Int. J. Mol. Sci. 19:4031. doi: 10.3390/ijms19124031

Kumar, R., Roy, I., Ohulchanskky, T. Y., Vathy, L. A., Bergey, E. J., Sajjad, M., et al. (2010). In vivo biodistribution and clearance studies using multimodal organically modified silica nanoparticles. ACS Nano 4, 699-708. doi: 10.1021/ nn901146y

Kumbhakar, D. V., Datta, A. K., Mandal, A., Das, D., Gupta, S., Ghosh, B., et al. (2016). Effectivity of copper and cadmium sulphide nanoparticles in mitotic and meiotic cells of Nigella sativa L. (black cumin) - can nanoparticles act as mutagenic agents? J. Exp. Nanosci. 11, 823-839. doi: 10.1080/17458080.2016. 1149236

Laha, D., Pramanik, A., Maity, J., Mukherjee, A., Pramanik, P., Laskar, A., et al. (2014). Interplay between autophagy and apoptosis mediated by copper oxide nanoparticles in human breast cancer cells MCF7. Biochim. Biophys. Acta Gen. Subj. 1840, 1-9. doi: 10.1016/j.bbagen.2013. 08.011

Lammel, T., Mackevica, A., Johansson, B. R., and Sturve, J. (2019). Endocytosis, intracellular fate, accumulation, and agglomeration of titanium dioxide ( $\mathrm{TiO} 2$ 2) nanoparticles in the rainbow trout liver cell line RTL-W1. Environ. Sci. Pollut. Res. 26, 15354-15372. doi: 10.1007/s11356-01904856-1

Lanone, S., Rogerieux, F., Geys, J., Dupont, A., Maillot-Marechal, E., Boczkowski, J., et al. (2009). Comparative toxicity of 24 manufactured nanoparticles in human alveolar epithelial and macrophage cell lines. Part. Fibre Toxicol. 6:14. doi: 10.1186/1743-8977-6-14
Lee, I. C., Ko, J. W., Park, S. H., Shin, N. R., Shin, I. S., Moon, C., et al. (2016). Comparative toxicity and biodistribution assessments in rats following subchronic oral exposure to copper nanoparticles and microparticles. Part. Fibre Toxicol. 13, 1-16. doi: 10.1186/s12989-016-0169-x

Levard, C., Hotze, E. M., Colman, B. P., Dale, A. L., Truong, L., Yang, X. Y., et al. (2013). Sulfidation of silver nanoparticles: natural antidote to their toxicity. Environ. Sci. Technol. 47, 13440-13448. doi: 10.1021/es403527n

Liu, W., Liu, S., and Wang, L. (2019). Surface modification of biomedical titanium alloy: micromorphology. Microstructure evolution and biomedical applications. Coatings 9:249. doi: 10.3390/coatings 9040249

Lu, G. W., and Gao, P. (2010). "CHAPTER 3 - emulsions and microemulsions for topical and transdermal drug delivery," in Handbook of Non-Invasive Drug Delivery Systems, ed. V. S. Kulkarni (Boston: William Andrew Publishing), 59-94.

Lu, X., Miousse, I. R., Pirela, S. V., Moore, J. K., Melnyk, S., Koturbash, I., et al. (2016). In vivo epigenetic effects induced by engineered nanomaterials: a case study of copper oxide and laser printer-emitted engineered nanoparticles. Nanotoxicology 10, 629-639. doi: 10.3109/17435390.2015.1108473

Luzio, J. P., Hackmann, Y., Dieckmann, N. M. G., and Griffiths, G. M. (2014). The biogenesis of lysosomes and lysosome-related organelles. Cold Spring Harb. Perspect. Biol. 6:a016840. doi: 10.1101/cshperspect.a016840

Manshian, B. B., Pokhrel, S., Mädler, L., and Soenen, S. J. (2018). The impact of nanoparticle-driven lysosomal alkalinization on cellular functionality. J. Nanobiotechnol. 16, 1-13. doi: 10.1186/s12951-018-0413-7

Marambio-Jones, C., and Hoek, E. M. V. (2010). A review of the antibacterial effects of silver nanomaterials and potential implications for human health and the environment. J. Nanoparticle Res. 12, 1531-1551. doi: 10.1007/s11051-0109900-y

Martirosyan, A., Bazes, A., and Schneider, Y. J. (2014). In vitro toxicity assessment of silver nanoparticles in the presence of phenolic compounds-preventive agents against the harmful effect? Nanotoxicology 8, 573-582. doi: 10.3109/ 17435390.2013 .812258

Miyayama, T., and Matsuoka, M. (2016). Involvement of lysosomal dysfunction in silver nanoparticle-induced cellular damage in A549 human lung alveolar epithelial cells. J. Occup. Med. Toxicol. 11:1. doi: 10.1186/s12995-016-0090-0

Mohammed, Y. H., Holmes, A., Haridass, I. N., Sanchez, W. Y., Studier, H., Grice, J. E., et al. (2019). Support for the safe use of zinc oxide nanoparticle sunscreens: lack of skin penetration or cellular toxicity after repeated application in volunteers. J. Invest. Dermatol. 139, 308-315. doi: 10.1016/j.jid.2018.08.024

Mordorski, B., and Friedman, A. (2017). "Metal nanoparticles for microbial infection," in Functionalized Nanomaterials for the Management of Microbial Infection, eds R. Boukherroub, S. Szunerits, and D. Drider (Amsterdam: Elsevier), 77-109.

Namvar, F., Rahman, H. S., Mohamad, R., Azizi, S., Tahir, P. M., Chartrand, M. S., et al. (2015). Cytotoxic effects of biosynthesized zinc oxide nanoparticles on murine cell lines. evidence-based complement. Altern. Med. 2015:593014. doi: $10.1155 / 2015 / 593014$

Nel, L. N., Xia, A., Mädler, L., and Li, N. (2006). Toxic potential of materials at the nanolevel. Science 311, 622-627. doi: 10.1126/science.1114397

Nemmar, A., Hoet, P. H. M., Vanquickenborne, B., Dinsdale, D., Thomeer, M., Hoylaerts, M. F., et al. (2002). Passage of inhaled particles into the blood circulation. Hum. Circ. 106, 411-414. doi: 10.1161/01.CIR.0000037134.24080. 42

Ng, C. T., Yong, L. Q., Hande, M. P., Ong, C. N., Yu, L. E., Bay, B. H., et al. (2017). Zinc oxide nanoparticles exhibit cytotoxicity and genotoxicity through oxidative stress responses in human lung fibroblasts and Drosophila melanogaster. Int. J. Nanomedicine 12, 1621-1637. doi: 10.2147/IJN.S1 24403

Osmond-McLeod, M. J., Osmond, R. I., Oytam, Y., McCall, M. J., Feltis, B., Mackay-Sim, A., et al. (2013). Surface coatings of $\mathrm{ZnO}$ nanoparticles mitigate differentially a host of transcriptional, protein and signalling responses in primary human olfactory cells. Part. Fibre Toxicol. 10:54. doi: 10.1186/17438977-10-54

Pacheco, I. I., Robbie, K., and Buzea, C. (2007). Nanomaterials and nanoparticles. Sour. Toxic. 2, 17-71.

Pan, Y., Leifert, A., Ruau, D., Neuss, S., Bornemann, J., Schmid, G., et al. (2009). Gold nanoparticles of diameter $1.4 \mathrm{~nm}$ trigger necrosis by oxidative stress and mitochondrial damage. Small 5, 2067-2076. doi: 10.1002/smll.200900466 
Pan, Y., Neuss, S., Leifert, A., Fischler, M., Wen, F., Simon, U., et al. (2007). Sizedependent cytotoxicity of gold nanoparticles. Small 3, 1941-1949. doi: 10.1002/ smll.200700378

Park, E.-J., Choi, J., Park, Y.-K., and Park, K. (2008). Oxidative stress induced by cerium oxide nanoparticles in cultured BEAS-2B cells. Toxicology 245, 90-100. doi: 10.1016/j.tox.2007.12.022

Park, H.-J., Kim, J. Y., Kim, J., Lee, J.-H., Hahn, J.-S., Gu, M. B., et al. (2009). Silverion-mediated reactive oxygen species generation affecting bactericidal activity. Water Res. 43, 1027-1032. doi: 10.1016/j.watres.2008.12.002

Pedata, P., Ricci, G., Malorni, L., Venezia, A., Cammarota, M., Volpe, M. G., et al. (2019). In vitro intestinal epithelium responses to titanium dioxide nanoparticles. Food Res. Int. 119, 634-642. doi: 10.1016/j.foodres.2018.10.041

Pelkonen, K. H. O., Heinonen-Tanski, H., and Hänninen, O. O. P. (2003). Accumulation of silver from drinking water into cerebellum and musculus soleus in mice. Toxicology 186, 151-157. doi: 10.1016/S0300-483X(02)00743-6

Pizzino, G., Irrera, N., Cucinotta, M., Pallio, G., Mannino, F., Arcoraci, V., et al. (2017). Oxidative stress: harms and benefits for human health. Oxid. Med. Cell. Longev. 2017, 1-13. doi: 10.1155/2017/8416763

Reidy, B., Haase, A., Luch, A., Dawson, K. A., and Lynch, I. (2013). Mechanisms of silver nanoparticle release, transformation and toxicity: a critical review of current knowledge and recommendations for future studies and applications. Materials 6, 2295-2350. doi: 10.3390/ma6062295

Roane, T. M., Rensing, C., Pepper, I. L., and Maier, R. M. (2009). "Chapter 21 - Microorganisms and Metal Pollutants," in Environmental Microbiology, 2nd Edn, eds I. L. Pepper, C. P. Gerba, T. J. Gentry, and R. M. Maier (San Diego: Academic Press), 421-441.

Ryu, H.-W., Lee, D. H., Florens, L., Swanson, S. K., Washburn, M. P., and Kwon, S. H. (2014). Analysis of the heterochromatin protein 1 (HP1) interactome in Drosophila. J. Proteomics 102, 137-147. doi: 10.1016/j.jprot.2014.03.016

Saliani, M., Jalal, R., and Goharshadi, E. K. (2016). Mechanism of oxidative stress involved in the toxicity of $\mathrm{ZnO}$ nanoparticles against eukaryotic cells. Nanomedicine J. 3, 1-14. doi: 10.7508/nmj.2016.01.001

Samberg, M. E., Oldenburg, S. J., and Monteiro-Riviere, N. A. (2010). Evaluation of silver nanoparticle toxicity in skin in vivo and keratinocytes in vitro. Environ. Health Perspect. 118, 407-413. doi: 10.1289/ehp.0901398

Semmler-Behnke, M., Kreyling, W. G., Lipka, J., Fertsch, S., Wenk, A., Takenaka, S., et al. (2008). Biodistribution of 1.4- and 18-nm gold particles in rats. Small 4, 2108-2111. doi: 10.1002/smll.200800922

Shah, J., Bhagat, S., and Singh, S. (2020). "Standard biological assays to estimate nanoparticle toxicity and biodistribution," in Nanotoxicity, eds S. Rajendran, A. Mukherjee, T.A. Nguyen, C. Godugu, and R.K. Shukla (Amsterdam: Elsevier), 71-104.

Sharma, V., Singh, P., Pandey, A. K., and Dhawan, A. (2012). Induction of oxidative stress, DNA damage and apoptosis in mouse liver after sub-acute oral exposure to zinc oxide nanoparticles. Mutat. Res. Genet. Toxicol. Environ. Mutagen. 745, 84-91. doi: 10.1016/j.mrgentox.2011.12.009

Shi, X., Zhu, Y., Hua, W., Ji, Y., Ha, Q., Han, X., et al. (2016). An in vivo study of the biodistribution of gold nanoparticles after intervaginal space injection in the tarsal tunnel. Nano Res. 9, 2097-2109. doi: 10.1007/s12274-016-1100-3

Shukla, R., Bansal, V., Chaudhary, M., Basu, A., Bhonde, R. R., and Sastry, M. (2005). Biocompatibility of gold nanoparticles and their endocytotic fate inside the cellular compartment: a microscopic overview. Langmuir 21, 10644-10654. doi: $10.1021 /$ la0513712

Sintubin, L., Verstraete, W., and Boon, N. (2012). Biologically produced nanosilver: current state and future perspectives. Biotechnol. Bioeng. 109, 2422-2436. doi: 10.1002/bit. 24570

Soenen, S. J., Parak, W. J., Rejman, J., and Manshian, B. (2015). (Intra)cellular stability of inorganic nanoparticles: effects on cytotoxicity, particle functionality, and biomedical applications. Chem. Rev. 115, 2109-2135. doi: $10.1021 / \mathrm{cr} 400714 \mathrm{j}$

Sonavane, G., Tomoda, K., and Makino, K. (2008). Biodistribution of colloidal gold nanoparticles after intravenous administration: effect of particle size. Colloids Surf. B Biointerfaces 66, 274-280. doi: 10.1016/j.colsurfb.2008.07.004

Stoccoro, A., Di Bucchianico, S., Coppedè, F., Ponti, J., Uboldi, C., and Blosi, M. (2017). Multiple endpoints to evaluate pristine and remediated titanium dioxide nanoparticles genotoxicity in lung epithelial A549 cells. Toxicol. Lett. 276, 48-61. doi: 10.1016/j.toxlet.2017. 05.016
Sukhanova, A., Bozrova, S., Sokolov, P., Berestovoy, M., Karaulov, A., and Nabiev, I. (2018). Dependence of nanoparticle toxicity on their physical and chemical properties. Nanoscale Res. Lett. 13:44. doi: 10.1186/s11671-018-2457-x

Suman, T. Y., Radhika Rajasree, S. R., and Kirubagaran, R. (2015). Evaluation of zinc oxide nanoparticles toxicity on marine algae chlorella vulgaris through flow cytometric, cytotoxicity and oxidative stress analysis. Ecotoxicol. Environ. Saf. 113, 23-30. doi: 10.1016/j.ecoenv.2014.11.015

Talamini, L., Violatto, M. B., Cai, Q., Monopoli, M. P., Kantner, K., Krpetiæ, $\check{Z}$, et al. (2017). Influence of size and shape on the anatomical distribution of endotoxin-free gold nanoparticles. ACS Nano 11, 5519-5529. doi: 10.1021/ acsnano.7b00497

Thai, S. F., Wallace, K. A., Jones, C. P., Ren, H., Prasad, R. Y., Ward, W. O., et al. (2015). Signaling pathways and microRNA changes in nano-TIO2 treated human lung epithelial (BEAS-2B) cells. J. Nanosci. Nanotechnol. 15, 492-503. doi: 10.1166/jnn.2015.9202

Thevenot, P., Cho, J., Wavhal, D., Timmons, R. B., and Tang, L. (2008). Surface chemistry influences cancer killing effect of $\mathrm{TiO} 2$ nanoparticles. Nanomedicine 4, 226-236. doi: 10.1016/j.nano.2008.04.001

Thit, A., Selck, H., and Bjerregaard, H. F. (2015). Toxic mechanisms of copper oxide nanoparticles in epithelial kidney cells. Toxicol. Vitr. 29, 1053-1059. doi: 10.1016/j.tiv.2015.03.020

Tiwari, D. K., Jin, T., and Behari, J. (2011). Dose-dependent in-vivo toxicity assessment of silver nanoparticle in Wistar rats. Toxicol. Mech. Methods 21, 13-24. doi: 10.3109/15376516.2010.529184

Trop, M., Novak, M., Rodl, S., Hellbom, B., Kroell, W., and Goessler, W. (2006). Silver-coated dressing acticoat caused raised liver enzymes and argyria-like symptoms in burn patient. J. Trauma Acute Care Surg. 60:1024.

Tsukahara, H. (2007). Biomarkers for oxidative stress: clinical application in pediatric medicine. Curr. Med. Chem. 14, 339-351. doi: 10.2174/ 092986707779941177

U.S. Food and Drug Administration (2019). USFDA, Code of Federal Regulations. Silver Spring, FL: Food and drug: , 21.

Valko, M., Morris, H., and Cronin, M. T. D. (2005). Metals, toxicity and oxidative stress. Curr. Med. Chem 12, 1161-1208. doi: 10.2174/0929867053764635

Vigneshwaran, N., Varadarajan, P. V., and Balasubramanya, R. H. (2010). "Application of Metallic Nanoparticles in Textiles," in Nanotechnologies Life Science, ed. P. Ram (Weinheim: Wiley-VCH Verlag GmbH \& Co. KGaA).

Vuong, N. Q., Goegan, P., Mohottalage, S., Breznan, D., Ariganello, M., Williams, A., et al. (2016). Proteomic changes in human lung epithelial cells (A549) in response to carbon black and titanium dioxide exposures. J. Proteomics 149, 53-63. doi: 10.1016/j.jprot.2016.03.046

Waghmode, M. S., Gunjal, A. B., Mulla, J. A., Patil, N. N., and Nawani, N. N. (2019). Studies on the titanium dioxide nanoparticles: biosynthesis, applications and remediation. SN Appl. Sci. 1:310. doi: 10.1007/s42452-019-0337-3

Wan, R., Mo, Y., Feng, L., Chien, S., Tollerud, D. J., and Zhang, Q. (2012). DNA damage caused by metal nanoparticles: the involvement of oxidative stress and activation of ATM Rong. Chem Res Toxicol. 25, 1402-1411. doi: 10.1021/ tx200513t

Wang, L., Xie, L., Shen, P., Fan, Q., Wang, W., Wang, K., et al. (2019). Surface microstructure and mechanical properties of Ti-6Al-4V/Ag nanocomposite prepared by FSP. Mater. Charact. 153, 175-183. doi: 10.1016/j.matchar.2019. 05.002

Wang, W., Han, P., Peng, P., Zhang, T., Liu, Q., and Yuan, S.-N. (2019). Friction stir processing of magnesium alloys: a review. Acta Metall. Sin. English Lett. 33, 43-57. doi: 10.1007/s40195-019-00971-7

Wang, X., Xia, T., Duch, M. C., Ji, Z., Zhang, H., Li, R., et al. (2012). Pluronic F108 coating decreases the lung fibrosis potential of multiwall carbon nanotubes by reducing lysosomal injury. Nano Lett. 12, 3050-3061. doi: 10.1021/nl300895y

Wijnhoven, S. W. P., Peijnenburg, W. J. G. M., Herberts, C. A., Hagens, W. I., Oomen, A. G., Heugens, E. H. W., et al. (2009). Nano-silver - a review of available data and knowledge gaps in human and environmental risk assessment. Nanotoxicology 3, 109-138. doi: 10.1080/17435390902725914

Xia, Y., Li, M., Peng, T., Zhang, W., Xiong, J., Hu, Q., et al. (2013). In vitro cytotoxicity of fluorescent silica nanoparticles hybridized with aggregationinduced emission luminogens, for living cell imaging. Int. J. Mol. Sci. 14, 1080-1092. doi: 10.3390/ijms14011080

Xie, Y., Williams, N. G., Tolic, A., Chrisler, W. B., Teeguarden, J. G., Maddux, B. L. S., et al. (2012). Aerosolized $\mathrm{ZnO}$ nanoparticles induce toxicity in alveolar 
type II epithelial cells at the air-liquid interface. Toxicol. Sci. 125, 450-461. doi: 10.1093/toxsci/kfr251

Xu, F., Piett, C., Farkas, S., Qazzaz, M., and Syed, N. I. (2013). Silver nanoparticles (AgNPs) cause degeneration of cytoskeleton and disrupt synaptic machinery of cultured cortical neurons. Mol. Brain 6:29. doi: 10.1186/1756-660 6-6-29

Xu, J., Shi, H., Ruth, M., Yu, H., Lazar, L., Zou, B., et al. (2013). Acute toxicity of intravenously administered titanium dioxide nanoparticles in mice. PLoS One 8:e70618. doi: 10.1371/journal.pone.0070618

Xu, L., Shi, C., Shao, A., Li, X., Cheng, X., Ding, R., et al. (2015). Toxic responses in rat embryonic cells to silver nanoparticles and released silver ions as analyzed via gene expression profiles and transmission electron microscopy. Nanotoxicology 9, 513-522. doi: 10.3109/17435390.2014. 948942

Yah, C. S. (2013). The toxicity of gold nanoparticles in relation to their physiochemical properties. Biomed. Res. 24, 400-413.

Yamanaka, M., Hara, K., and Kudo, J. (2005). Bactericidal actions of a silver ion solution on Escherichia coli Studied by energy-filtering transmission electron microscopy and proteomic analysis. Appl. Environ. Microbiol. 71, 7589-7593. doi: 10.1128/AEM.71.11.7589-7593.2005

Yang, H., Liu, C., Yang, D., Zhang, H., and Xi, Z. (2009). Comparative study of cytotoxicity, oxidative stress and genotoxicity induced by four typical nanomaterials: the role of particle size, shape and composition. J. Appl. Toxicol. 29, 69-78. doi: 10.1002/jat.1385

Yang, W., Shen, C., Ji, Q., An, H., Wang, J., Liu, Q., et al. (2009). Food storage material silver nanoparticles interfere with DNA replication fidelity and bind with DNA. Nanotechnology 20:085102. doi: 10.1088/0957-4484/20/8/08 5102

Yang, Z., Gu, H., Sha, G., Lu, W., Yu, W., Zhang, W., et al. (2018). TC4/Ag metal matrix nanocomposites modified by friction stir processing: surface characterization. antibacterial property, and cytotoxicity in vitro. ACS Appl. Mater. Interfaces 10, 41155-41166. doi: 10.1021/acsami.8b 16343

Yen, H.-J., Hsu, S., and Tsai, C.-L. (2009). Cytotoxicity and immunological response of gold and silver nanoparticles of different sizes. Small 5, 1553-1561. doi: 10.1002/smll.200900126

Yu, K., Yoon, T., Minai-tehrani, A., Kim, J., Jin, S., Sook, M., et al. (2013). Toxicology in Vitro Zinc oxide nanoparticle induced autophagic cell death and mitochondrial damage via reactive oxygen species generation. Toxicol. Vitr. 27, 1187-1195. doi: 10.1016/j.tiv.2013. 02.010

Yu, L. E., Lanry Yung, L.-Y., Ong, C.-N., Tan, Y.-L., Suresh Balasubramaniam, K., and Hartono, D. (2007). Translocation and effects of gold nanoparticles after inhalation exposure in rats. Nanotoxicology 1, 235-242. doi: 10.1080/ 17435390701763108
Zhang, C., Ding, Z., Xie, L., Zhang, L.-C., Wu, L., Fu, Y., et al. (2017). Electrochemical and in vitro behavior of the nanosized composites of Ti-6Al$4 \mathrm{~V}$ and $\mathrm{TiO} 2$ fabricated by friction stir process. Appl. Surf. Sci. 423, 331-339. doi: 10.1016/j.apsusc.2017.06.141

Zhang, S., Gao, H., and Bao, G. (2015). Physical principles of nanoparticle cellular endocytosis. ACS Nano 9, 8655-8671. doi: 10.1021/acsnano.5b03184

Zhang, X., Zhang, H., Liang, X., Zhang, J., Tao, W., Zhu, X., et al. (2016). Iron oxide nanoparticles induce autophagosome accumulation through multiple mechanism: lysosome impairment, mitochondrial damage and ER stress. Mol. Pharm. 13, 2578-2587. doi: 10.1021/acs.molpharmaceut.6b00405

Zhang, X.-F., Gurunathan, S., and Kim, J.-H. (2015). Effects of silver nanoparticles on neonatal testis development in mice. Int. J. Nanomedicine 10, 6243-6256. doi: 10.2147/IJN.S90733

Zhang, Y., Ding, Z., Zhao, G., Zhang, T., Xu, Q., Cui, B., et al. (2018). Transcriptional responses and mechanisms of copper nanoparticle toxicology on zebrafish embryos. J. Hazard. Mater. 344, 1057-1068. doi: 10.1016/j.jhazmat. 2017.11.039

Zhao, H., Chen, L., Zhong, G., Huang, Y., Zhang, X., Chu, C., et al. (2019) Titanium dioxide nanoparticles induce mitochondrial dynamic imbalance and damage in HT22 cells. J. Nanomater. 2019, 1-16. doi: 10.1155/2019/4607531

Zhao, X., Ng, S., Heng, B. C., Guo, J., Ma, L., and Tan, T. T. Y. (2013). Cytotoxicity of hydroxyapatite nanoparticles is shape and cell dependent. Arch. Toxicol. 87, 1037-1052. doi: 10.1007/s00204-0120827-1

Zhou, X., Zhao, L., Luo, J., Tang, H., Xu, M., Wang, Y., et al. (2019). The toxic effects and mechanisms of nano-cu on the spleen of rats. Int. J. Mol. Sci. 20:1469. doi: 10.3390/ijms20061469

Zhu, Y., Eaton, J. W., and Li, C. (2012). Titanium dioxide (TiO2) nanoparticles preferentially induce cell death in transformed cells in a Bak/Bax-independent fashion. PLoS One 7:e50607. doi: 10.1371/journal.pone.0050607

Zoroddu, M. A., Medici, S., Ledda, A., Nurchi, V. M., Lachowicz, J. I., and Peana, M. (2014). Toxicity of nanoparticles. Curr. Med. Chem. 21, 3837-3853. doi: $10.2174 / 0929867321666140601162314$

Conflict of Interest: The authors declare that the research was conducted in the absence of any commercial or financial relationships that could be construed as a potential conflict of interest.

Copyright (C) 2020 Attarilar, Yang, Ebrahimi, Wang, Liu, Tang and Yang. This is an open-access article distributed under the terms of the Creative Commons Attribution License (CC BY). The use, distribution or reproduction in other forums is permitted, provided the original author(s) and the copyright owner(s) are credited and that the original publication in this journal is cited, in accordance with accepted academic practice. No use, distribution or reproduction is permitted which does not comply with these terms. 